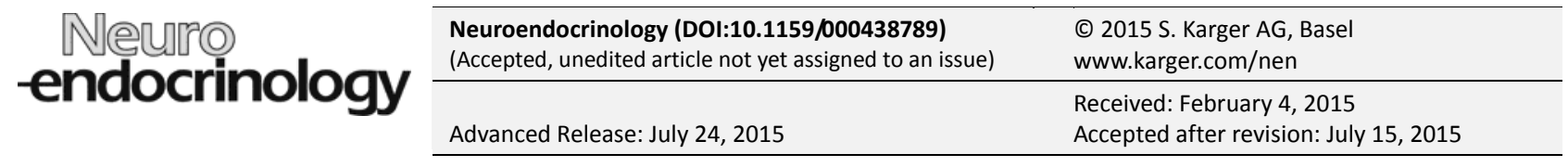

\title{
Neuroprotective effect of progesterone in MPTP-treated male mice
}

Mélanie Bourque ${ }^{a, b}$, Marc Morissette ${ }^{a}$, Sara Al Sweidi ${ }^{a, b}$, Donatella Caruso ${ }^{c}$, Roberto C. Melcangi ${ }^{c}$, Thérèse Di Paolo ${ }^{\mathrm{a}, \mathrm{b}, *}$

${ }^{a}$ Neuroscience Research Unit, Centre Hospitalier Universitaire de Québec, CHUL, Quebec City, Quebec, G1V 4G2

${ }^{\text {b} F a c u l t y ~ o f ~ P h a r m a c y, ~ L a v a l ~ U n i v e r s i t y, ~ Q u e b e c ~ C i t y, ~ Q u e b e c, ~ G 1 K ~ 7 P 4, ~ C a n a d a ~}$

${ }^{\mathrm{c}}$ Department of Pharmacological and Biomolecular Sciences, Center of Excellence on Neurodegenerative Diseases, Università degli Studi di Milano, 20133 Milano, Italy

Short title: Protective effect of progesterone

* Correspondence and reprint requests should be addressed to:

Dr. Thérèse Di Paolo

Neuroscience Research Unit

Centre Hospitalier Universitaire de Québec

2705 Laurier Boulevard, Quebec, Qc, Canada, G1V 4G2

Tel: (418) 654-2296; Fax: (418) 654-2761;

E-mail: therese.dipaolo@crchul.ulaval.ca 


\section{ABSTRACT}

Background: Numerous studies have reported the neuroprotective activity of estradiol whereas the effect of the other ovarian steroid progesterone is much less documented. Methods: This study sought to investigate neuroprotection with a low dose of progesterone $(1 \mu \mathrm{g})$ in 1-methyl-4-phenyl1,2,3,6-tetrahydropyridine (MPTP)-treated male mice, to model Parkinson's disease, and compare them to the effect of this steroid in intact mice (experiment 1). We also investigated if high doses of progesterone could protect dopaminergic neurons already exposed to MPTP (experiment 2). We measured progesterone effects on various dopaminergic markers (dopamine and its metabolites, dopamine transporter (DAT), vesicular monoamine transporter 2 (VMAT2)) and on neuroactive steroids in both plasma and brain. Results: For experiment 1, our results showed that progesterone prevented completely MPTP toxicity on dopamine concentrations, on the increase of 3methoxytyramine/dopamine ratio, as well as VMAT2 specific binding in the striatum and the substantia nigra. Progesterone decreased MPTP effects on DOPAC concentration and DAT specific binding in the lateral part of the anterior striatum and in the middle striatum (medial and lateral parts). Progesterone treatment in intact mice had no effect on the markers investigated. For experiment 2, measures of dopaminergic markers in striatum showed that $8 \mathrm{mg} / \mathrm{kg}$ of progesterone was the most effective dose to reduce MPTP effects, and more limited effects were observed with 16 $\mathrm{mg} / \mathrm{kg}$. We found that progesterone treatment increases the levels of brain progesterone itself and also of its metabolites. Conclusion: Our result showed that progesterone has neuroprotective effects on dopaminergic neurons in MPTP male mice.

Keywords: neuroprotection, progesterone, MPTP, dopamine, neuroactive steroids 


\section{INTRODUCTION}

Parkinson's disease (PD) is the second most common neurodegenerative disorder and is likely to increase due to the aging population. The major pathology in PD is the selective and progressive death of dopamine (DA) cell bodies in substantia nigra. There is presently no cure for PD and the most common treatments (levodopa and DA agonists) improve motor symptoms without preventing or delaying the degenerative process [1]. Nevertheless, as the disease progresses, these therapies eventually lose effectiveness for many patients and major motor complications such as dyskinesia often appear [1]. Therefore, neuroprotective compounds that could prevent the loss of DA neurons or reverse the progression of PD are critically needed.

Several studies have reported that men are at greater risk of developing PD than women [24], suggesting that ovarian hormone have a beneficial influence on the risk to develop PD. Animal models supported the neuroprotective effect of $17 \beta$-estradiol against the damage to the nigrostriatal neurons induced by 1-methyl-4-phenyl-1,2,3,6-tetrahydropyridine (MPTP) in mice and by lesion with 6-hydroxydopamine (6-OHDA) in rats $[5,6]$. The beneficial effect of progesterone (PROG) has been less studied than that of $17 \beta$-estradiol, but several animals and clinical studies have shown that PROG shows beneficial effect against brain damage. PROG has been reported to have protective effects on the dopaminergic terminals in mice expose to MPTP or methamphetamine [7-9]. Moreover, studies have highlighted that PROG has a beneficial effect when administered following traumatic brain injury, both in animal models and in human [10-12] but very recent clinical studies found no beneficial effects and may be because of the complexity and heterogeneity of the disorder $[13,14]$. There is presently no therapy (drug that slows, stops, or reverses disease progression) recognized to have a neuroprotective effect in PD patients $[15,16]$, and PROG could be a good candidate to delay the progression or rescue neurons in PD patients.

The present study sought to extend our previous findings concerning the neuroprotective effect of a low dose of PROG $(1 \mu \mathrm{g})[7,9]$. First, given that PROG is a neuromodulator [17], we have differentiated the neuroprotective versus neuromodulatory effect of PROG on the DA system, by 
investigating and comparing the effect of PROG in intact, non-lesioned, and in MPTP-treated mice with measures of DA, DA transporter (DAT) and vesicular monoamine transporter 2 (VMAT2). In a second experiment, we investigated if high doses of PROG had the capacity to protect dopaminergic neurons that have been exposed to MPTP in male mice. Furthermore, we have measured how plasma and brain levels of several neuroactive steroids are modulated following MPTP lesion and treatment with PROG. 


\section{MATERIALS AND METHODS}

\section{Animals and Treatment}

C57BI/6 male mice (10 weeks) were purchased from Charles River Canada (Montreal, Qc, Canada). MPTP and PROG were purchased from Sigma Chemical (St. Louis, MO, USA). The Laval University Animal Care Committee approved all of the animal studies. All efforts were made to minimize animal suffering and to reduce the number of mice used.

\section{Experiment 1}

Each group of mice (average weight $24.33 \pm 0.19 \mathrm{~g})$ received treatment with PROG $(1 \mu \mathrm{g}$, twice daily, subcutaneous) or vehicle ( $0.9 \%$ saline with $0.3 \%$ gelatin, twice daily, subcutaneous) for 10 days. On day 5, mice received four intraperitoneal injections of MPTP $(11 \mathrm{mg} / \mathrm{kg})$ at 2-h intervals, whereas the control groups received saline solution. This acute MPTP model induced a decrease of approximately $50 \%$ in striatal DA concentration as well as in DAT and VMAT2 specific binding in striatum [18]. No change in tyrosine hydroxylase immunoreactivity are observed in the substantia nigra in this model [18]. On day 11 , mice were decapitated, and brains were quickly removed and frozen in isopentane $\left(-40^{\circ} \mathrm{C}\right)$.

\section{Experiment 2}

Mice (average weight $23.87 \pm 0.12 \mathrm{~g}$ ) received four intraperitoneal injections of MPTP (6.5 $\mathrm{mg} / \mathrm{kg}$ ) at 2-h intervals, whereas the control groups received saline solution. A similar dose of PROG as in the neuroprotection experiment $1(1 \mu \mathrm{g})$ was investigated under conditions of experiment 2 . One hour after the first MPTP injection, mice received one intraperitoneal injection of PROG. One hour after the last injection of MPTP, mice received one subcutaneous injection with PROG. During the next five days, mice received two daily subcutaneous injections with PROG. For all the dopaminergic markers measured, this treatment regimen gave no or modest protective activity (our unpublished results). Hence, consistent with reported rescue results with PROG in 6-OHDA rats [19, 
20] we used higher doses of PROG in the present experiment. One hour after the first MPTP injection, mice received one intraperitoneal injection of PROG ( $8 \mathrm{mg} / \mathrm{kg}$ (191 $\mu \mathrm{g}$ per injection) or 16 $\mathrm{mg} / \mathrm{kg}(382 \mu \mathrm{g}$ per injection)). One hour after the last injection of MPTP, mice received one subcutaneous injection with PROG ( $8 \mathrm{mg} / \mathrm{kg}$ or $16 \mathrm{mg} / \mathrm{kg}$ ). During the next five days, mice received one $(8 \mathrm{mg} / \mathrm{kg}$ or $16 \mathrm{mg} / \mathrm{kg}$ ) daily subcutaneous injection with PROG. On day 6 , mice were decapitated, and brains were quickly removed and frozen in isopentane $\left(-40^{\circ} \mathrm{C}\right)$.

\section{Brain preparation}

One mouse brain hemisphere was used to measure DA markers and the other for steroid concentrations analyses. A unilateral striatum was used to assay DA and its metabolites concentrations. The striatum anterior (bregma 1.54 to 1.18 ), middle (bregma 0.50 to 0.14 ) and posterior (bregma -0.34 to $-0.70 \mathrm{~mm}$ ) and the substantia nigra (bregma -2.80 to $-3.88 \mathrm{~mm}$ ) [21] of the contralateral hemisphere were cut on a cryostat in $12 \mu \mathrm{m}$ slices. Slices were maintained at $-80^{\circ} \mathrm{C}$ until assay.

\section{Striatal biogenic amines determination}

The left anterior striata were dissected, homogenized in $250 \mu \mathrm{l}$ of $0.1 \mathrm{~N} \mathrm{HClO}_{4}$ at $4{ }^{\circ} \mathrm{C}$ and then centrifuged at $10000 \times \mathrm{g}$ for $10 \mathrm{~min}\left(4^{\circ} \mathrm{C}\right)$ to precipitate proteins. The concentrations of DA and its metabolites 3,4-dihydroxyphenylacetic acid (DOPAC), 3-methoxytyramine (3-MT) and homovanillic acid (HVA), as well as serotonin and its metabolite 5-hydroxyindoleacetic acid (5-HIAA), were measured by high performance liquid chromatography (HPLC) with electrochemical detection as we previously described $[7,22,23]$. Supernatants of striatal tissue were directly injected into the chromatograph consisting of a Waters 717 plus autosampler automatic injector, a Waters 515 pump equipped with a C-18 column (Waters Nova-Pak C18, $3 \mu \mathrm{m}, 3.9 \mathrm{~mm} \times 150 \mathrm{~cm}$ ), a BAS LC-4C electrochemical detector and a glassy carbon electrode. The mobile phase consisted of $0.025 \mathrm{M}$ citric acid, $1.7 \mathrm{mM}$ 1-heptane-sulfonic acid, and 10\% methanol, in filtered distilled water, delivered at a 
flow rate of $0.8 \mathrm{ml} / \mathrm{min}$. The final $\mathrm{pH}$ of 4.1 was obtained by addition of $\mathrm{NaOH}$. The electrochemical potential was set at $0.8 \mathrm{~V}$ with respect to an $\mathrm{Ag} / \mathrm{AgCl}$ reference electrode. Biogenic amines values were normalized to protein concentrations and results were expressed in nanograms of amine per milligram of protein. Proteins were assayed with a Micro BCA Protein Assay kit (Thermo Scientific, Rockford, IL).

\section{Dopamine transporter autoradiography}

DAT autoradiography in the striatum and the substantia nigra was performed as previously described [9]. DAT specific binding used $20 \mathrm{pmol}$ of the ligand $\left.3 \beta-\left(4-{ }^{125}\right)\right]$ iodophenyl)tropane-2 $\beta-$ carboxylic acid isopropyl ester ([ $\left.\left.{ }^{125} \mathrm{I}\right]-\mathrm{RTI}-121\right)$ (2200 Ci/mmol, PerkinElmer, Boston, MA, USA). Nonspecific binding was evaluated with binding in the presence of $100 \mathrm{nM}$ of Mazindol (Sandoz Pharmaceuticals, Dorval, Quebec). Brain slices were apposed to Kodak films (Biomax) 18 hours for the striatum and 30 hours for substantia nigra. Films were analyzed using the software NIH Image 1.63.

\section{Vesicular monoamine transporter 2}

VMAT2 autoradiography in the striatum and the substantia nigra was performed using the specific ligand $\left[{ }^{3} \mathrm{H}\right]$ dihydrotetrabenazine $\left(\left[{ }^{3} \mathrm{H}\right]-\mathrm{TBZ}-\mathrm{OH}\right.$, American Radiolabeled Chemicals, St. Louis, $\mathrm{MO}, \mathrm{USA})$ [24]. Specific binding was evaluated using $20 \mathrm{nM}$ of $\left[{ }^{3} \mathrm{H}\right]-\mathrm{TBZ}-\mathrm{OH}(20 \mathrm{Ci} / \mathrm{mmol})$ and $1 \mu \mathrm{M}$ of cold TBZ-OH for the non-specific binding. Slices were exposed to Kodak films (Biomax), 4 weeks for the striatum and 6 weeks for the substantia nigra. Films were analyzed using the software NIH Image 1.63. 


\section{Quantification of steroids}

\section{Quantification of steroids in mouse plasma of neuroprotection experiment 1}

The plasma levels of testosterone, dihydrotestosterone (DHT), $5 \alpha$-androstane-3 $\beta, 17 \beta$-diol (3ß-diol) and PROG were measured with gas chromatography mass spectrometry as described [25]. Plasma of 2 or 3 mice from the same group and with similar DA concentrations was pooled in order to have enough plasma to quantify the steroid concentrations.

\section{Quantification of neuroactive steroids in mouse plasma and brain of neuroprotection experiment 2}

Quantitative analysis of steroids (pregnenolone (PREG), PROG, dihydroprogesterone (DHP), isopregnanolone (ISOPREG), tetrahydroprogesterone (THP, allopregnanolone),

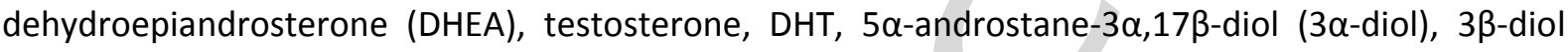
and $17 \beta$-estradiol by liquid chromatography tandem mass spectrometry (LC-MS/MS) was performed as reported [26]. One brain hemisphere was used to measure brain steroid concentrations. The mice brain samples were analyzed individually whereas pools of 2-3 mice from the same group and with similar DA concentrations were used in order to have enough plasma to quantify the steroid concentrations. A large number of plasma and brain samples had $17 \beta$-estradiol concentrations under the detection limit of quantification $(0.02 \mathrm{pg} / \mu \mathrm{lor} \mathrm{pg} / \mathrm{mg})$ for all the experimental groups hence this data was not included.

\section{Statistical analysis}

Statistical comparisons of the data were performed with a one-way analysis of variance (ANOVA) using Stat View 4.51 for Macintosh Computer software, followed by a post-hoc analysis with a Fisher's protected least significant difference test. A simple regression model was used to determine the coefficient of correlation. A $p<0.05$ was required for the results to be considered statistically significant. 


\section{RESULTS}

\section{Neuroprotection experiment 1}

\section{Dopaminergic markers}

In intact nonlesioned mice, PROG treatment had no effect on striatal DA (Figure 1A) and its metabolites DOPAC (Figure 1B), 3-MT (Figure 1C) and HVA (Figure 1D) concentrations as well as on striatal serotonin and its metabolite 5-HIAA concentrations (Figure $1 \mathrm{H}$ and I). Administration of MPTP decreased striatal DA concentrations (decrease of $49 \%$ ) (Figure 1A) as well as DOPAC (decrease of 48 \%) (Figure 1B), 3-MT (decrease of $35 \%$ ) (Figure 1C) and HVA (decrease of $45 \%$ ) (Figure 1D) concentrations and increased 3-MT/DA ratio (Figure 1F). MPTP at the dose used showed specificity to the DA system, striatal serotonin and 5-HIAA concentrations showing no significant difference between groups (Figure $1 \mathrm{H}, \mathrm{I}$ and J). Treatment with PROG prevented completely the MPTP toxicity on DA concentrations (Figure $1 \mathrm{~A}$ ) as well as the increase of 3-MT/DA ratio (Figure $1 \mathrm{~F}$ ) and partially the decrease on DOPAC content (Figure 1B).

PROG treatment had no effect on DAT specific binding in the striatum of nonlesioned mice (Figure $2 \mathrm{~A}$ and $\mathrm{C}$ ). Measures of DAT specific binding in all region of the striatum showed a decrease in MPTP-treated mice as compared to control values (Figure 2A and C). PROG was effective in reducing MPTP toxicity on DAT specific binding in the lateral part of the anterior striatum as well as in the medial and lateral parts of the middle striatum. No significant difference between groups was observed for DAT specific binding in substantia nigra pars compacta (Figure 2B and C).

No statistically significant differences in VMAT2 specific binding in the striatum were observed between control mice and PROG treated, nonlesioned, mice (Figure 3A and C). MPTP mice showed a decrease in VMAT2 specific binding in all the areas of the striatum measured (Figure 3A and B). PROG treatment reduced MPTP toxicity as measured with VMAT2 specific binding in the medial and lateral parts of the anterior, middle and posterior striatum. In substantia nigra, PROG treatment did not change VMAT2 specific binding in nonlesioned mice (Figure 3B and C). Nigral 
VMAT2 specific binding was slightly reduced in MPTP treated mice whereas PROG + MPTP treated mice were at control levels.

\section{Plasma concentration of steroids}

Measures of steroid plasma levels showed that PROG treatment in intact mice induces a decrease in the levels of testosterone, DHT and $3 \beta$-diol (Figure 4). Lower levels of the androgens testosterone, DHT and $3 \beta$-diol were observed in MPTP mice as compared to control mice. MPTP mice receiving PROG treatment had significantly higher levels of testosterone and DHT than MPTP mice receiving vehicle. An increase in plasma levels of PROG was observed in MPTP mice treated with PROG.

\section{Neuroprotection experiment 2}

\section{Dopaminergic markers}

Administration of MPTP induced a significant decrease in concentrations of DA $165 \%$ decrease compared to the control group) (Figure 5A). A dose-response effect of PROG was observed when the steroid was administered after MPTP. The dose of $8 \mathrm{mg} / \mathrm{kg}$ of PROG, but not $16 \mathrm{mg} / \mathrm{kg}$, significantly reduced the effect of MPTP, with a $53 \%$ increase in DA concentrations as compared to MPTP mice. Administration of PROG (8 $\mathrm{mg} / \mathrm{kg}$ ) also reduced the effect of MPTP on concentrations of DOPAC (Figure 5B) and on the ratio of 3-MT/DA (Figure 5F). PROG at both doses tested reduced the increase in the ratio of HVA/DA induced by MPTP (Figure 5G). No significantly change in striatal serotonin concentrations was observed (Figure 5H). MPTP mice and MPTP mice treated with PROG (all doses) had higher 5-HIAA concentrations and superior 5-HIAA/serotonin ratio than control mice (Figure $5 \mathrm{I}$ and J). Mice treated with $16 \mathrm{mg} / \mathrm{kg}$ of PROG had a decrease of striatal 5-HIAA concentrations as compared to MPTP mice (Figure 5I). Only the dose of $8 \mathrm{mg} / \mathrm{kg}$ of PROG significantly reduced the effect of MPTP on the 5-HIAA/serotonin ratio (Figure 5J). 
Both doses of PROG significantly decreased the effect of MPTP on DAT specific binding in the medial and lateral parts of the anterior striatum (Figure 6A and C). Increased DAT specific binding as compared to MPTP was observed with the $8 \mathrm{mg} / \mathrm{kg}$ dose of PROG, both for the medial and lateral parts of the middle striatum. Moreover, in both the medial and lateral parts of the posterior striatum, PROG $(8 \mathrm{mg} / \mathrm{kg})$ treatment was effective in reducing the MPTP effect. In the substantia nigra pars compacta, MPTP mice treated with PROG $(8 \mathrm{mg} / \mathrm{kg})$ had DAT specific binding at control values (Figure 6B and C). A decrease in DAT specific binding was observed in MPTP mice and in mice receiving $16 \mathrm{mg} / \mathrm{kg}$ of PROG.

For VMAT2 specific binding, only PROG administered at the dose of $8 \mathrm{mg} / \mathrm{kg}$ reduced MPTP toxicity in the medial and lateral parts of the anterior and middle striatum, and also in the medial part of the posterior striatum (Figure 7A and C). Moreover, in the medial part of the posterior striatum, PROG administered at $8 \mathrm{mg} / \mathrm{kg}$ reduced MPTP effect. When mice were treated with 16 $\mathrm{mg} / \mathrm{kg}$ of PROG, a decrease in MPTP effect was observed in the lateral part of the posterior striatum. Reduction in nigral VMAT2 specific binding was observed in MPTP mice and in mice treated with doses of 8 and $16 \mathrm{mg} / \mathrm{kg}$ of PROG (Figure 7B and C).

\section{Plasma and brain concentration of neuroactive steroids}

We next addressed by LC-MS/MS whether neuroactive steroid levels in plasma and brain tissue were changed by MPTP lesion and by treatment with different doses of PROG. A schematic representation of biosynthesis pathways of steroids assayed is presented in Figure 8 .

Data obtained showed that among PREG, PROG and its derivatives, only DHP and ISOPREG were significantly affected in MPTP-treated male mice (Figure 9A). In particular, these two neuroactive steroids were increased in plasma. PROG treatments showed in plasma a dosedependent increase in PROG levels; assessment of PROG metabolites revealed that both doses of PROG administered decreased DHP levels as compared to MPTP mice, while only the highest dose of PROG was able to significantly decrease the levels of ISOPREG. THP levels were not affected in 
MPTP-treated male mice, and $24 \mathrm{~h}$ after the last PROG treatment no change was observed (Figure 9A).

In brain tissue (Figure 9A), the levels of all these neuroactive steroids were unchanged in MPTP-treated male mice, however treatment with PROG at the highest dose was able to significantly increase PREG, PROG, DHP, ISOPREG and THP (Figure 9A). Interestingly, PROG treatment at the dose of $8 \mathrm{mg} / \mathrm{kg}$ was able to decrease the levels of PREG and increase PROG and THP levels in brain tissue. Significant positive correlations were observed between plasma and brain levels of PROG and a significant negative correlation was found between plasma and brain levels of ISOPREG (Figure 9B).

As reported in Figure 10A, the levels of testosterone metabolites DHT, $3 \alpha$-diol and $3 \beta$-diol were significantly decreased in the plasma of MPTP-treated male mice, while no change was observed for DHEA and testosterone as compared to control group. By contrast, in brain tissue, only the levels of DHT were changed and were significantly increased (Figure 10A). In brain tissue, treatment with PROG at the dose of $8 \mathrm{mg} / \mathrm{kg}$ was able to decrease the levels of DHT as compared to MPTP mice, while after treatment with the highest dose, a significant increase was observed. In brain tissue, the levels of DHEA and $3 \beta$-diol were not modified in MPTP-treated male mice, but affected by PROG treatment. Thus, the dose of $16 \mathrm{mg} / \mathrm{kg}$ was able to significantly decrease the levels of these two neuroactive steroids. Significant positive correlations were observed between plasma and brain levels of DHEA, as well as between plasma and brain levels of testosterone; a significant negative correlation was found between plasma and brain levels of DHT (Figure 10B). Brain and plasma levels of $17 \beta$-estradiol remained low or under the detection limit in all experimental groups showing no effect of PROG treatment (data not shown). 


\section{DISCUSSION}

The present results showed that a low dose of PROG has a neuroprotective effect and at higher doses PROG has beneficial effects on dopaminergic neurons exposed to MPTP. The present results support our previous publications on the neuroprotective effect of PROG in MPTP retired breeder mice $[7,9]$. At a dose of $1 \mu \mathrm{g}$, PROG reduced the effect of MPTP when a moderate lesion of the nigrostriatal dopaminergic system is present (experiment 1), but had limited effect in experiment 2 (our unpublished results), when dopaminergic neurons have been already exposed to MPTP. A higher dose of PROG was required to observe an effect on dopaminergic markers in experiment 2; a dose of $8 \mathrm{mg} / \mathrm{kg}$ was neuroprotective while $16 \mathrm{mg} / \mathrm{kg}$ PROG had more limited effects.

Although data on the beneficial effect of PROG on brain trauma is abundant [27], few studies investigated the potential protective role of PROG on dopaminergic neurons exposed to toxin inducing damage. A study in rats lesioned with 6-OHDA showed that administration of chronic PROG $(8 \mathrm{mg} / \mathrm{kg}) 24$ hours post-injury increased the metabolism of striatal DA and exacerbated motor deficits induced by the lesion [19]. In contrast, others reported that the administration of high doses of PROG (4 mg/kg) seven days after the striatal injection of 6-OHDA improved motor and cognitive deficits [20]. Although in the present study the therapeutic window of opportunity of PROG was not investigated, and PROG was administered in a relatively short time after the lesion, the study with rats injured with 6-OHDA [20] suggests that the therapeutic window of opportunity of PROG is relatively long, with benefits seen after a long period following the lesion. This data suggests that PROG could be an interesting candidate to delay the degeneration of DA neurons.

Accumulation of PROG after its intraperitoneal administration is reported to be higher in the brain than in plasma [28]. Thus, high levels of PROG is quickly found in the brain after injection, allowing a rapid action of this steroid in the brain. PROG exerts is action by binding to two nuclear receptors, PROG receptor (PR)-A and PR-B [29]. In addition, PROG also binds to membrane PROG receptor (mPR) $\alpha$ and $\beta$ [30]. PR-A, PR-B and mPR- $\alpha$ are expressed in the striatum [31, 32]. PR-A, PR-B and mPR- $\beta$ have been found in the substantia nigra [33-35]. Whereas the mechanisms of PROG 
action in the striatum have received little attention, PROG is reported to mediate its effect through multiple mechanisms. PROG increases brain mitochondrial efficiency by reducing leakage and reducing lipid peroxidation, supporting its ability to increase the oxidative capacity of brain mitochondria and thus to reduce oxidative stress [36]. THP (allopregnanolone), an active metabolite of PROG, has anti-apoptotic effects by inhibiting the opening of the permeability transition pore and inhibiting the mitochondrial release of cytochrome c [37]. In cultured neurons of the striatum, PROG blocks neuronal death occurring by depolarization induced by opening voltage-gated calcium channels by blocking the entry of calcium in these channels [38]. This effect of PROG requires high concentrations and cannot be blocked by the use of a nuclear receptor antagonist, suggesting a mechanism independent of the activation of these receptors [38]. PROG increases the activity of Akt and ERK1/2, both major kinases involved in cell survival $[12,39]$. PROG also has anti-inflammatory properties and its action reduces the inflammatory response following brain damage [40, 41]. By activation of nuclear receptors, PROG increases levels of brain-derived neurotrophic factor [42], a neurotrophic factor involved in neuroprotection and in maintaining neurons function [43]. PROG increases the expression of the mitochondrial anti-apoptotic protein $\mathrm{Bcl}-2$ [44], and was reported to decrease oxidative stress by increasing the levels of endogenous antioxidants such as glutathione, superoxide dismutase and catalase [45].

PROG has active metabolites, DHP and THP, which are reported to have beneficial effects on the brain $[46,47]$. The two enzymes responsible for conversion of PROG to DHP and, subsequently, to THP, the $5 \alpha$-reductase and the $3 \alpha$-hydroxysteroid dehydrogenase, are present in the brain [48]. It is therefore possible that the neuroprotective effect observed in the present study is due to metabolism of PROG. Our results showed that an increase in brain levels of PROG and THP occurred following PROG treatment at the doses investigated, while brain levels of DHP and ISOPREG were only increased with $16 \mathrm{mg} / \mathrm{kg}$ of PROG. THP and ISOPREG are modulators of GABA-A receptor [49], it is therefore possible that the increase of brain levels of THP and ISOPREG modulate GABA-A receptor. A high accumulation of brain PROG and its metabolites was not associated with 
neuroprotection levels, since more limited effect of PROG treatment was observed on dopaminergic markers when administered at the dose of $16 \mathrm{mg} / \mathrm{kg}$. In support of the role of PROG metabolites in neuroprotection, several in vitro and in vivo studies have shown that blockage of the $5 \alpha$-reductase, the first enzyme involved in the conversion of PROG into DHP, abolishes the neuroprotective effect of PROG in various models [50-52]. Furthermore, administration of THP once weekly for two weeks in MPTP mice is reported to restore positive cells for tyrosine hydroxylase in the substantia nigra as well as motor behavior, and induce the generation of new positive neurons for tyrosine hydroxylase in substantia nigra [53]. THP in this study was administered at a time when the damage induced by MPTP is stable, that is after seven days [54]. Thus, THP has potent capacity of recovery and neurogenesis of tyrosine hydroxylase neurons. Nevertheless, its remains to be investigated whether the conversion of PROG to DHP and THP has a role in the neuroprotective effect of PROG in dopaminergic neurons in MPTP-treated mice; this could be done by blocking $5 \alpha$-reductase activity.

High levels of PROG and its metabolites DHP and THP were found in the human brain [55]. A decrease of $5 \alpha$-reductase, the enzyme responsible of the conversion of PROG to its metabolites, were observed in the substantia nigra of PD patients [56]. This reduction could account for the decreased levels of THP and DHP found in the cerebrospinal fluid of PD patients [57]. Moreover, alteration in PROG metabolism have been also reported in a different animal model of PD [58]. Further work is needed to investigate how the decrease in PROG metabolites contributes to the degenerative process, but current data suggests that PROG could be an interesting therapeutic compound since THP is known to modulate dopaminergic systems, to act as a positive neuromodulator of GABA-A receptors and to have neuroprotective effects [53, 59]. Future studies that compare the neuroprotective effect of PROG and THP on dopaminergic neurons could also be very informative, as THP could potential be used instead of PROG when $5 \alpha$-reductase activity is impaired, as reported to occur in PD patients.

MPTP is reported to induce damage to Leydig cells [60] causing a decrease in plasma androgens levels $[60,61]$, as shown in the present study. We also observed a reduction in plasma 
androgens levels in intact and MPTP mice treated with PROG. The effect of PROG on androgen biosynthesis is reported to be mediated by its inhibitory effect on luteinizing hormone, which is responsible for the production of testosterone by Leydig cells [62]. An increase of brain DHT was observed in MPTP mice and with PROG treatment at $16 \mathrm{mg} / \mathrm{kg}$. A previous study from our group reported a lack of protective effect on dopaminergic markers in MPTP mice receiving androgens treatment [63], suggesting that an increase in brain androgen concentrations is not implicated in the limited protective effect of PROG observed at the dose of $16 \mathrm{mg} / \mathrm{kg}$.

We find that changes in brain steroids levels following PROG treatment did not necessarily reflect the changes observed in plasma levels. Not only treatment with steroid such as progesterone results in different levels of steroids in plasma and brain, a study reported that intact male and female rodents show differences between their plasma and brain levels for some steroids, with sex difference observed [64]. Thus, measures of steroids in plasma may not be always valuable to predict their brain levels.

PROG is reported to modulate DA activity as shown by a rapid increase in striatal DA, DOPAC and HVA concentrations in rodents $[65,66]$. Thus, our results obtained in MPTP mice treated with PROG could be caused by a hormonal effect on DA synthesis or metabolism. Nevertheless, we reported that chronic treatment with PROG in intact male mice did not modulate DA and turnover, DAT and VMAT2 specific binding, whereas PROG treated MPTP mice had higher DA, DAT and VMAT2 than vehicle treated MPTP mice. Thus, the results presented here support that the DA changes observed involve neuroprotection rather than only modulation of DA activity.

Studies in both men and women have shown the beneficial effect of PROG administration to reduce damage following traumatic brain injury $[10,11]$. No side effects from the use of high dose of PROG in the short term have been reported in patients with a traumatic brain injury [10, 11]. PROG is sometimes used in monotherapy to treat symptoms of menopause in women and few side effects were observed during long-term use with low, medium or high doses [67]. PROG represent an interesting therapeutic option for brain disease that could be used in both men and women. 
In this study, we have shown that the use of low dose of PROG had neuroprotective capacities by decreasing the toxic effects of MPTP in dopaminergic neurons. Furthermore, administration of PROG at higher doses induced protective effects on dopaminergic neurons that have been already exposed to MPTP.

\section{ACKNOWLEDGEMENT}

This work was supported by a grant from the Canadian Institutes of Health Research (CIHR) MOP82692 to TDP. 


\section{REFERENCES}

1 Olanow CW, Stern MB, Sethi K: The scientific and clinical basis for the treatment of parkinson disease (2009). Neurology 2009;72:S1-136.

2 Van Den Eeden SK, Tanner CM, Bernstein AL, Fross RD, Leimpeter A, Bloch DA, Nelson LM: Incidence of parkinson's disease: Variation by age, gender, and race/ethnicity. Am J Epidemiol 2003;157:1015-1022.

3 Wooten GF, Currie LJ, Bovbjerg VE, Lee JK, Patrie J: Are men at greater risk for parkinson's disease than women? J Neurol Neurosurg Psychiatry 2004;75:637-639.

4 Shulman LM: Gender differences in parkinson's disease. Gend Med 2007;4:8-18.

5 Baraka AM, Korish AA, Soliman GA, Kamal H: The possible role of estrogen and selective estrogen receptor modulators in a rat model of parkinson's disease. Life Sci 2011;88:879-885.

6 Bourque M, Dluzen DE, Di Paolo T: Neuroprotective actions of sex steroids in parkinson's disease. Front Neuroendocrinol 2009;30:142-157.

7 Grandbois M, Morissette M, Callier S, Di Paolo T: Ovarian steroids and raloxifene prevent mptp-induced dopamine depletion in mice. Neuroreport 2000;11:343-346.

8 Yu L, Liao PC: Estrogen and progesterone distinctively modulate methamphetamineinduced dopamine and serotonin depletions in c57bl/6j mice. J Neural Transm 2000;107:1139-1147.

9 Callier S, Morissette M, Grandbois M, Pelaprat D, Di Paolo T: Neuroprotective properties of 17beta-estradiol, progesterone, and raloxifene in mptp c57bl/6 mice. Synapse 2001;41:131-138.

10 Wright DW, Kellermann AL, Hertzberg VS, Clark PL, Frankel M, Goldstein FC, Salomone JP, Dent LL, Harris OA, Ander DS, Lowery DW, Patel MM, Denson DD, Gordon AB, Wald MM, Gupta S, Hoffman SW, Stein DG: Protect: A randomized clinical trial of 
progesterone for acute traumatic brain injury. Ann Emerg Med 2007;49:391-402, 402 e391392.

11 Xiao G, Wei J, Yan W, Wang W, Lu Z: Improved outcomes from the administration of progesterone for patients with acute severe traumatic brain injury: A randomized controlled trial. Crit Care 2008;12:R61.

12 Ishrat T, Sayeed I, Atif F, Hua F, Stein DG: Progesterone is neuroprotective against ischemic brain injury through its effects on the phosphoinositide 3-kinase/protein kinase b signaling pathway. Neuroscience 2012;210:442-450.

13 Wright DW, Yeatts SD, Silbergleit R, Palesch YY, Hertzberg VS, Frankel M, Goldstein FC, Caveney AF, Howlett-Smith H, Bengelink EM, Manley GT, Merck LH, Janis LS, Barsan WG, Investigators N: Very early administration of progesterone for acute traumatic brain injury. N Engl J Med 2014;371:2457-2466.

14 Skolnick BE, Maas AI, Narayan RK, van der Hoop RG, MacAllister T, Ward JD, Nelson NR, Stocchetti N, Investigators ST: A clinical trial of progesterone for severe traumatic brain injury. N Engl J Med 2014;371:2467-2476.

15 Olanow CW, Schapira AH: Therapeutic prospects for parkinson disease. Ann Neurol 2013;74:337-347.

16 AlDakheel A, Kalia LV, Lang AE: Pathogenesis-targeted, disease-modifying therapies in parkinson disease. Neurotherapeutics 2014;11:6-23.

17 Sanchez MG, Bourque M, Morissette M, Di Paolo T: Steroids-dopamine interactions in the pathophysiology and treatment of cns disorders. CNS Neurosci Ther 2010;16:e43-71. 18 Bourque M, Morissette M, Cote M, Soulet D, Di Paolo T: Implication of gper1 in neuroprotection in a mouse model of parkinson's disease. Neurobiol Aging 2013;34:887-901. 19 Chao OY, Huston JP, von Bothmer A, Pum ME: Chronic progesterone treatment of male rats with unilateral 6-hydroxydopamine lesion of the dorsal striatum exacerbates [corrected] parkinsonian symptoms. Neuroscience 2011;196:228-236. 
20 Casas S, Garcia S, Cabrera R, Nanfaro F, Escudero C, Yunes R: Progesterone prevents depression-like behavior in a model of parkinson's disease induced by 6-hydroxydopamine in male rats. Pharmacol Biochem Behav 2011;99:614-618.

21 Franklin K, Paxinos G: The mouse brain in stereotaxic coordinates. San Diego, Academic Press, 1997.

22 D'Astous M, Morissette M, Tanguay B, Callier S, Di Paolo T: Dehydroepiandrosterone (dhea) such as 17beta-estradiol prevents mptp-induced dopamine depletion in mice. Synapse 2003;47:10-14.

23 Morissette M, Jourdain S, Al Sweidi S, Menniti FS, Ramirez AD, Di Paolo T: Role of estrogen receptors in neuroprotection by estradiol against mptp toxicity. Neuropharmacology 2007;52:1509-1520.

24 Kilbourn M, Frey K: Striatal concentrations of vesicular monoamine transporters are identical in mptp-sensitive (c57bl/6) and -insensitive (cd-1) mouse strains. Eur J Pharmacol 1996;307:227-232.

25 Audet-Walsh E, Lepine J, Gregoire J, Plante M, Caron P, Tetu B, Ayotte P, Brisson J, Villeneuve L, Belanger A, Guillemette C: Profiling of endogenous estrogens, their precursors, and metabolites in endometrial cancer patients: Association with risk and relationship to clinical characteristics. J Clin Endocrinol Metab 2011;96:E330-339.

26 Caruso D, Pesaresi M, Maschi O, Giatti S, Garcia-Segura LM, Melcangi RC: Effect of short-and long-term gonadectomy on neuroactive steroid levels in the central and peripheral nervous system of male and female rats. J Neuroendocrinol 2010;22:1137-1147.

27 Sayeed I, Stein DG: Progesterone as a neuroprotective factor in traumatic and ischemic brain injury. Prog Brain Res 2009;175:219-237.

28 Wong R, Ray D, Kendall DA: Progesterone pharmacokinetics in the mouse: Implications for potential stroke therapy. J Pharm Pharmacol 2012;64:1614-1620. 
29 Schumacher M, Mattern C, Ghoumari A, Oudinet JP, Liere P, Labombarda F, SitrukWare R, De Nicola AF, Guennoun R: Revisiting the roles of progesterone and allopregnanolone in the nervous system: Resurgence of the progesterone receptors. Prog Neurobiol 2014;113:6-39.

30 Singh M, Su C, Ng S: Non-genomic mechanisms of progesterone action in the brain. Front Neurosci 2013;7:159.

31 Wu HB, Fabian S, Jenab S, Quinones-Jenab V: Progesterone receptors activation after acute cocaine administration. Brain Res 2006;1126:188-192.

32 Meffre D, Labombarda F, Delespierre B, Chastre A, De Nicola AF, Stein DG, Schumacher M, Guennoun R: Distribution of membrane progesterone receptor alpha in the male mouse and rat brain and its regulation after traumatic brain injury. Neuroscience 2013;231:111-124.

33 Lonstein JS, Blaustein JD: Immunocytochemical investigation of nuclear progestin receptor expression within dopaminergic neurones of the female rat brain. J Neuroendocrinol 2004;16:534-543.

34 Curran-Rauhut MA, Petersen SL: The distribution of progestin receptor mrna in rat brainstem. Brain Res Gene Expr Patterns 2002;1:151-157.

35 Zuloaga DG, Yahn SL, Pang Y, Quihuis AM, Oyola MG, Reyna A, Thomas P, Handa RJ, Mani SK: Distribution and estrogen regulation of membrane progesterone receptor-beta in the female rat brain. Endocrinology 2012;153:4432-4443.

36 Irwin RW, Yao J, Hamilton RT, Cadenas E, Brinton RD, Nilsen J: Progesterone and estrogen regulate oxidative metabolism in brain mitochondria. Endocrinology 2008;149:31673175.

37 Sayeed I, Parvez S, Wali B, Siemen D, Stein DG: Direct inhibition of the mitochondrial permeability transition pore: A possible mechanism for better neuroprotective effects of allopregnanolone over progesterone. Brain Res 2009;1263:165-173. 
38 Luoma JI, Kelley BG, Mermelstein PG: Progesterone inhibition of voltage-gated calcium channels is a potential neuroprotective mechanism against excitotoxicity. Steroids 2011;76:845-855.

39 Guerra-Araiza C, Amorim MA, Pinto-Almazan R, Gonzalez-Arenas A, Campos MG, Garcia-Segura LM: Regulation of the phosphoinositide-3 kinase and mitogen-activated protein kinase signaling pathways by progesterone and its reduced metabolites in the rat brain. J Neurosci Res 2009;87:470-481.

40 Gibson CL, Constantin D, Prior MJ, Bath PM, Murphy SP: Progesterone suppresses the inflammatory response and nitric oxide synthase-2 expression following cerebral ischemia. Exp Neurol 2005;193:522-530.

41 Stein DG: The case for progesterone. Ann N Y Acad Sci 2005;1052:152-169.

42 Jodhka PK, Kaur P, Underwood W, Lydon JP, Singh M: The differences in neuroprotective efficacy of progesterone and medroxyprogesterone acetate correlate with their effects on brain-derived neurotrophic factor expression. Endocrinology 2009;150:3162-3168. 43 Aron L, Klein R: Repairing the parkinsonian brain with neurotrophic factors. Trends Neurosci 2011;34:88-100.

44 Yao XL, Liu J, Lee E, Ling GS, McCabe JT: Progesterone differentially regulates proand anti-apoptotic gene expression in cerebral cortex following traumatic brain injury in rats. J Neurotrauma 2005;22:656-668.

45 Aggarwal R, Medhi B, Pathak A, Dhawan V, Chakrabarti A: Neuroprotective effect of progesterone on acute phase changes induced by partial global cerebral ischaemia in mice. $\mathrm{J}$ Pharm Pharmacol 2008;60:731-737.

46 Leonelli E, Bianchi R, Cavaletti G, Caruso D, Crippa D, Garcia-Segura LM, Lauria G, Magnaghi V, Roglio I, Melcangi RC: Progesterone and its derivatives are neuroprotective agents in experimental diabetic neuropathy: A multimodal analysis. Neuroscience 2007;144:1293-1304. 
47 Wang JM, Singh C, Liu L, Irwin RW, Chen S, Chung EJ, Thompson RF, Brinton RD: Allopregnanolone reverses neurogenic and cognitive deficits in mouse model of alzheimer's disease. Proc Natl Acad Sci U S A 2010;107:6498-6503.

48 Do Rego JL, Seong JY, Burel D, Leprince J, Luu-The V, Tsutsui K, Tonon MC, Pelletier G, Vaudry H: Neurosteroid biosynthesis: Enzymatic pathways and neuroendocrine regulation by neurotransmitters and neuropeptides. Front Neuroendocrinol 2009;30:259-301.

49 Belelli D, Lambert JJ: Neurosteroids: Endogenous regulators of the gaba(a) receptor. Nat Rev Neurosci 2005;6:565-575.

50 Singh S, Hota D, Prakash A, Khanduja KL, Arora SK, Chakrabarti A: Allopregnanolone, the active metabolite of progesterone protects against neuronal damage in picrotoxin-induced seizure model in mice. Pharmacol Biochem Behav 2010;94:416-422.

51 Radley E, Akram A, Grubb BD, Gibson CL: Investigation of the mechanisms of progesterone protection following oxygen-glucose deprivation in organotypic hippocampal slice cultures. Neurosci Lett 2012;506:131-135.

52 Ishihara Y, Kawami T, Ishida A, Yamazaki T: Allopregnanolone-mediated protective effects of progesterone on tributyltin-induced neuronal injury in rat hippocampal slices. $\mathrm{J}$ Steroid Biochem Mol Biol 2012;135C:1-6.

53 Adeosun SO, Hou X, Jiao Y, Zheng B, Henry S, Hill R, He Z, Pani A, Kyle P, Ou X, Mosley T, Farley JM, Stockmeier C, Paul I, Bigler S, Brinton RD, Smeyne R, Wang JM: Allopregnanolone reinstates tyrosine hydroxylase immunoreactive neurons and motor performance in an mptp-lesioned mouse model of parkinson's disease. PLoS One 2012;7:e50040.

54 L'Episcopo F, Tirolo C, Testa N, Caniglia S, Morale MC, Cossetti C, D'Adamo P, Zardini E, Andreoni L, Ihekwaba AE, Serra PA, Franciotta D, Martino G, Pluchino S, Marchetti B: Reactive astrocytes and wnt/beta-catenin signaling link nigrostriatal injury to 
repair in 1-methyl-4-phenyl-1,2,3,6-tetrahydropyridine model of parkinson's disease. Neurobiol Dis 2011;41:508-527.

55 Bixo M, Andersson A, Winblad B, Purdy RH, Backstrom T: Progesterone, 5alphapregnane-3,20-dione and 3alpha-hydroxy-5alpha-pregnane-20-one in specific regions of the human female brain in different endocrine states. Brain Res 1997;764:173-178.

56 Luchetti S, Bossers K, Frajese GV, Swaab DF: Neurosteroid biosynthetic pathway changes in substantia nigra and caudate nucleus in parkinson's disease. Brain Pathol 2010;20:945-951.

57 di Michele F, Longone P, Romeo E, Lucchetti S, Brusa L, Pierantozzi M, Bassi A, Bernardi G, Stanzione P: Decreased plasma and cerebrospinal fluid content of neuroactive steroids in parkinson's disease. Neurol Sci 2003;24:172-173.

58 Melcangi RC, Caruso D, Levandis G, Abbiati F, Armentero MT, Blandini F: Modifications of neuroactive steroid levels in an experimental model of nigrostriatal degeneration: Potential relevance to the pathophysiology of parkinson's disease. J Mol Neurosci 2012;46:177-183.

59 Zheng P: Neuroactive steroid regulation of neurotransmitter release in the cns: Action, mechanism and possible significance. Prog Neurobiol 2009;89:134-152.

60 Ruffoli R, Giambelluca MA, Scavuzzo MC, Pasquali L, Giannessi F, Fornai F: Mptpinduced parkinsonism is associated with damage to leydig cells and testosterone loss. Brain Res 2008;1229:218-223.

61 Bourque M, Morissette M, Di Paolo T: Raloxifene activates g protein-coupled estrogen receptor 1/akt signaling to protect dopamine neurons in 1-methyl-4-phenyl-1,2,3,6tetrahydropyridine mice. Neurobiol Aging 2014;35:2347-2356.

62 Jeyaraj DA, Mani Maran RR, Aruldhas MM, Govindarajulu P: Progesterone induced modulations of serum hormonal profiles in adult male and female rats. Endocr Res 2001;27:223-232. 
63 Ekue A, Boulanger JF, Morissette M, Di Paolo T: Lack of effect of testosterone and dihydrotestosterone compared to 17beta-oestradiol in 1-methyl-4-phenyl-1,2,3,6, tetrahydropyridine-mice. J Neuroendocrinol 2002;14:731-736.

64 Caruso D, Pesaresi M, Abbiati F, Calabrese D, Giatti S, Garcia-Segura LM, Melcangi RC: Comparison of plasma and cerebrospinal fluid levels of neuroactive steroids with their brain, spinal cord and peripheral nerve levels in male and female rats. Psychoneuroendocrinology 2013;38:2278-2290.

65 Di Paolo T, Levesque D, Daigle M: A physiological dose of progesterone affects rat striatum biogenic amine metabolism. Eur J Pharmacol 1986;125:11-16.

66 Petitclerc M, Bedard PJ, Di Paolo T: Progesterone releases dopamine in male and female rat striatum: A behavioral and microdialysis study. Prog Neuropsychopharmacol Biol Psychiatry 1995;19:491-497.

67 Spark MJ, Willis J: Systematic review of progesterone use by midlife and menopausal women. Maturitas 2012;72:192-202. 


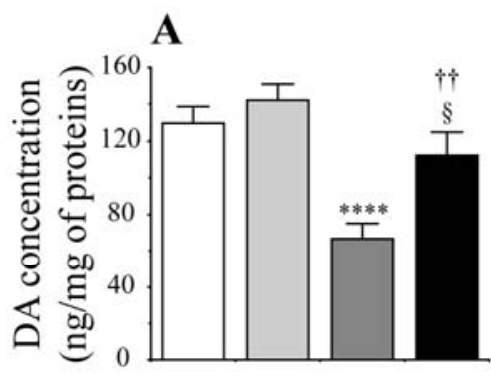

Control

PROG
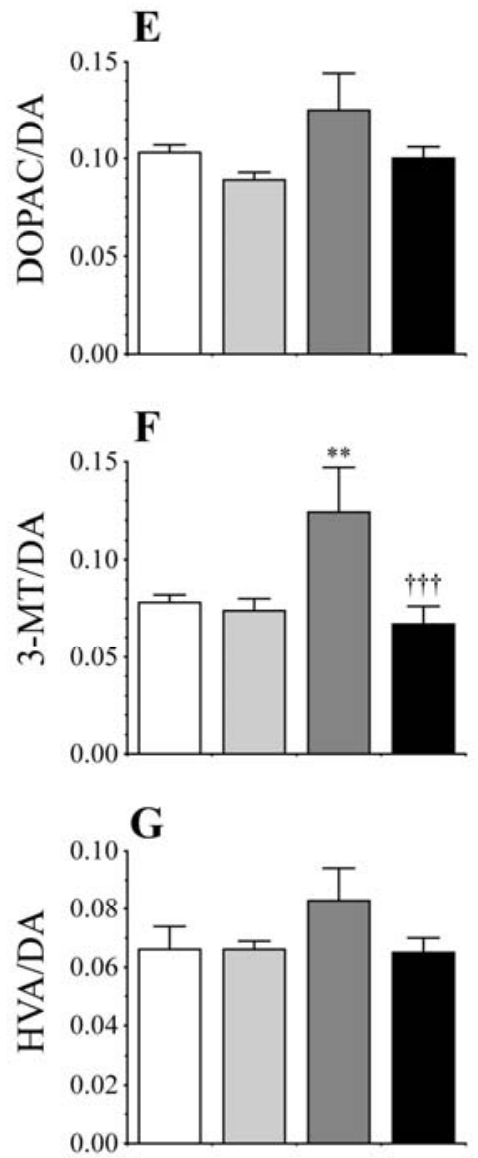
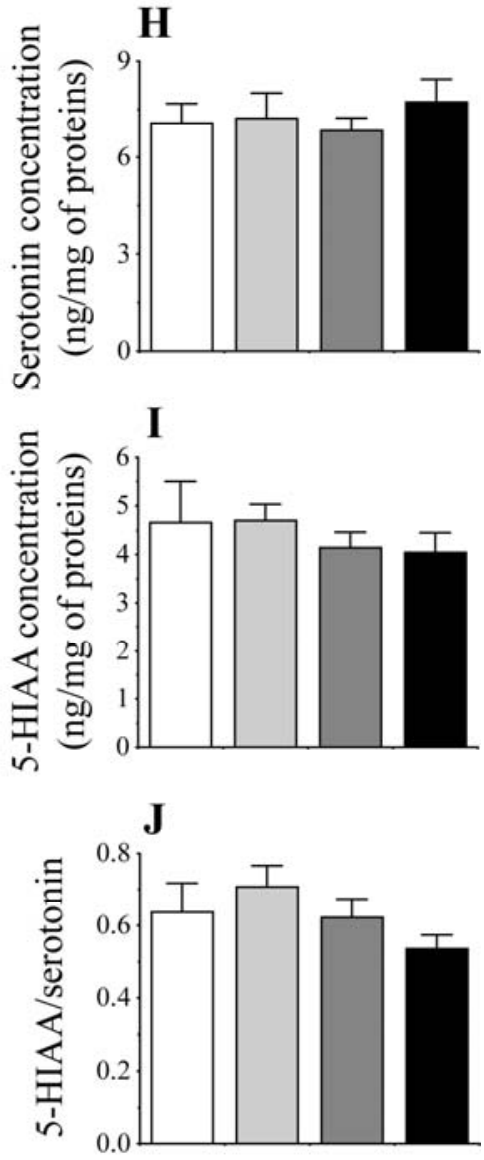

Figure 1. Effects of MPTP and neuroprotection with PROG treatment (experiment 1) on (A) dopamine (DA) concentrations and its metabolites (B) 3,4-dihydroxyphenylacetic acid (DOPAC), (C) 3methoxytyramine (3-MT) and (D) homovanillic acid (HVA), (E) DOPAC/DA, (F) 3-MT/DA and (G) HVA/DA ratios, as well as (H) serotonin concentrations, its metabolite (I) 5-hydroxyindoleacetic acid (5-HIAA), and (J) 5-HIAA/serotonin ratio. Mice were treated with PROG twice daily ( $1 \mu \mathrm{g})$ for ten days ( 5 days before and 5 days after MPTP administration). Values shown are the means $(\mathrm{ng} / \mathrm{mg}$ of proteins) \pm S.E.M. of 10-12 mice per group. There was a statistically significant effect of treatment for $\operatorname{DA}(F[3,41]=11.82 ; p<0.0001), \operatorname{DOPAC}(F[3,41]=13.14 ; p<0.0001), 3-\mathrm{MT}(F[3,41]=6.78 ; p=$ 0.0008), HVA $(F[3,41]=4.29 ; p=0.01)$ and 3-MT/DA $(F[3,41]=4.13 ; p=0.012) .{ }^{*} p<0.05,{ }^{* *} p<$ 
<smiles>CC1CC1</smiles> 

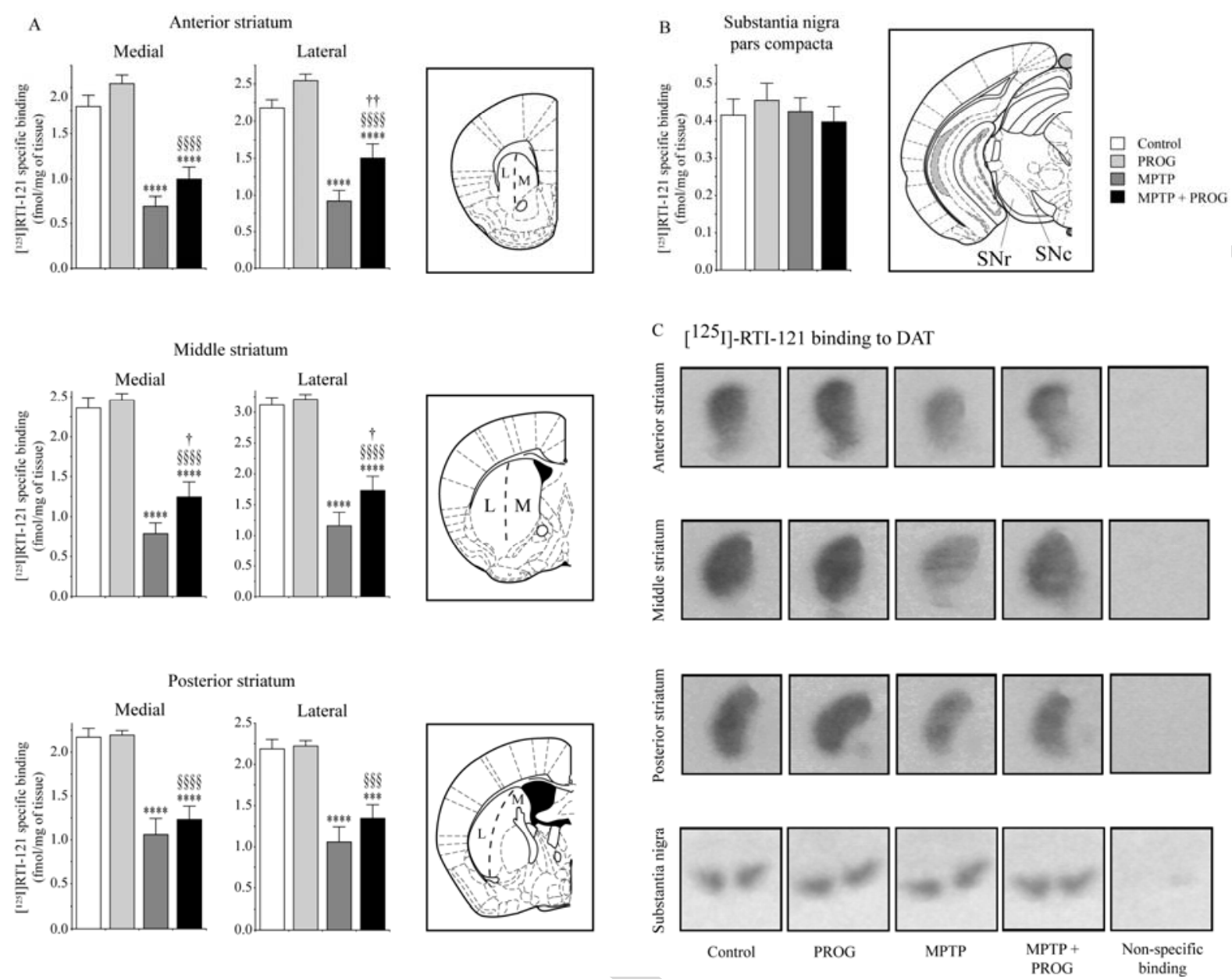

Figure 2. Effects of MPTP and neuroprotection with PROG treatment (experiment 1) on [ $\left.{ }^{125} \mathrm{I}\right]-\mathrm{RTI}-121$

DAT specific binding in (A) striatum and (B) substantia nigra pars compacta, with the schematic of the mouse brain showing the subdivisions of the striatum in the lateral $(\mathrm{L})$ and medial $(\mathrm{M})$ parts (adapted from the atlas of Franklin and Paxinos [21]). Mice were treated with PROG twice daily (1 $\mu \mathrm{g})$ for ten days ( 5 days before and 5 days after MPTP administration). Values shown are the means (fmol/mg of tissue) \pm S.E.M. of 10-12 mice per group. There was a statistically significant effect of treatment for medial part of the anterior striatum $(F[3,41]=30.62 ; p<0.0001)$, lateral part of the anterior striatum $(F[3,41]=28.15 ; p<0.0001)$, medial part of the middle striatum $(F[3,40]=41.08 ; p<0.0001)$, lateral part of the middle striatum $(F[3,40]=36.21 ; p=0.0004)$, medial part of the posterior striatum $(F[3,41]=20.04 ; p<0.0001)$, and lateral part of the posterior striatum $(F[3,41]=16.56 ; p<0.0001)$. $* * * p<0.005$ and ${ }^{* * * *} \mathrm{p}<0.0001$ vs control; $\S \S \S \mathrm{p}<0.005$ and $\S \S \S \S \mathrm{p}<0.0001$ vs PROG; $+\mathrm{p}<0.05$ and $+\dagger p<0.01$ vs MPTP. C. Representative examples of autoradiograms showing $\left[{ }^{125} \mathrm{I}\right]-\mathrm{RTI}-121$ 
<smiles>C1=C2CC1C2</smiles> 

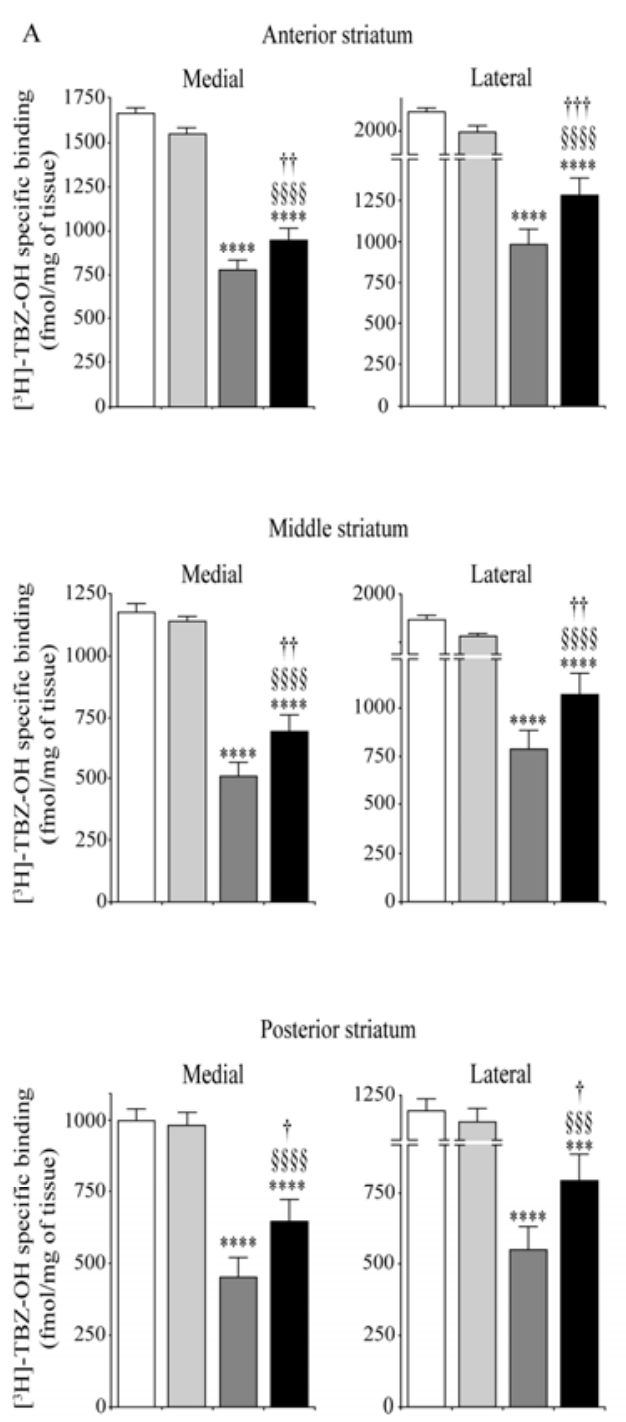

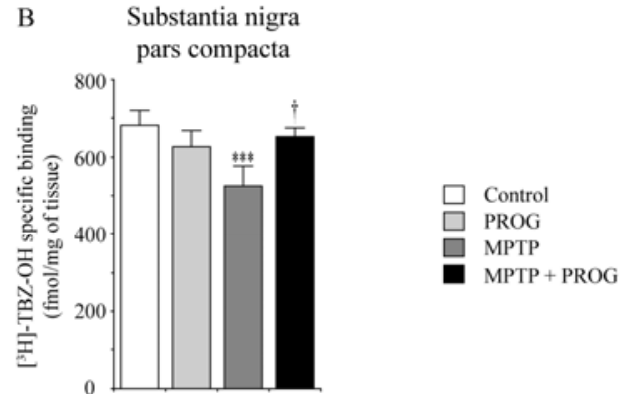

$\mathrm{C}$

$\left[{ }^{3} \mathrm{H}\right]-\mathrm{TBZ}-\mathrm{OH}$ binding to VMAT2
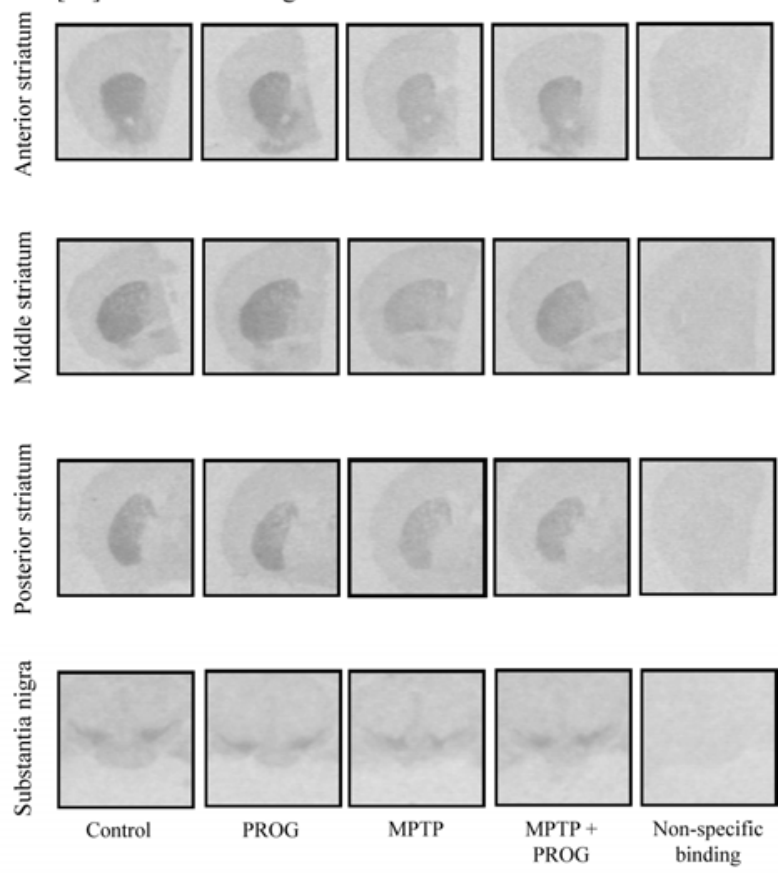

Figure 3. Effects of MPTP and neuroprotection with PROG treatment (experiment 1 ) on $\left[{ }^{3} \mathrm{H}\right]-\mathrm{TBZ}-\mathrm{OH}$ VMAT2 specific binding in (A) striatum and (B) substantia nigra pars compacta. Mice were treated with PROG twice daily $(1 \mu \mathrm{g})$ for ten days ( 5 days before and 5 days after MPTP administration). Values shown are the means ( $\mathrm{fmol} / \mathrm{mg}$ of tissue) \pm S.E.M. of $10-12$ mice per group. There was a statistically significant effect of treatment for medial part of the anterior striatum $(F[3,41]=89.74 ; p$ $<0.0001)$, lateral part of the anterior striatum $(F[3,41]=62.01 ; p<0.0001)$, medial part of the middle striatum $(F[3,40]=50.70 ; p<0.0001)$, lateral part of the middle striatum $(F[3,40]=54.29 ; p<$ $0.0004)$, medial part of the posterior striatum $(F[3,41]=26.65 ; p<0.0001)$, lateral part of the posterior striatum $(F[3,41]=20.03 ; p<0.0001)$ and for substantia nigra $(F[3,41]=3.15 ; p=0.035)$. ${ }^{* * *} \mathrm{p}<0.005$ and $* * * * p<0.0001$ vs control; $\S \S \S<<0.005$ and $\S \S \S \S p<0.0001$ vs PROG; ${ }^{\dagger} \mathrm{p}<0.05$ 
<smiles>C1=C2CC1C2</smiles> 
Testosterone

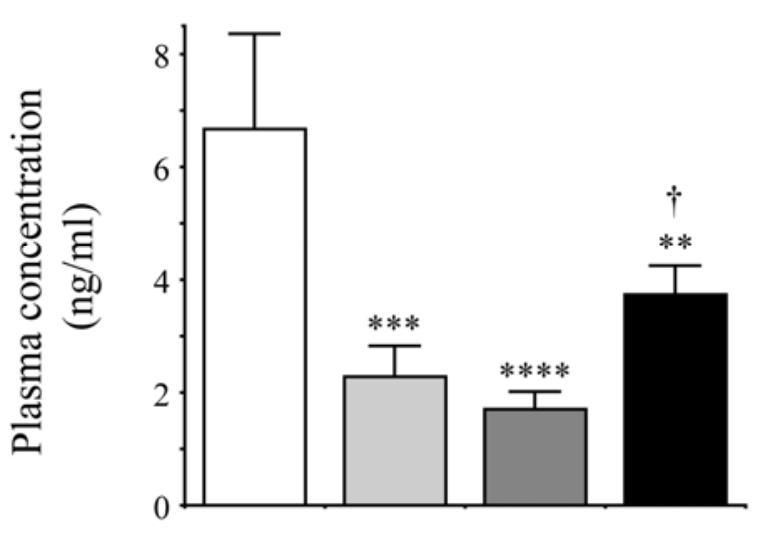

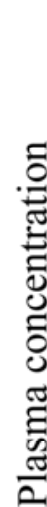

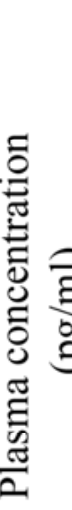

\section{DHT}

200
150
100
50
0
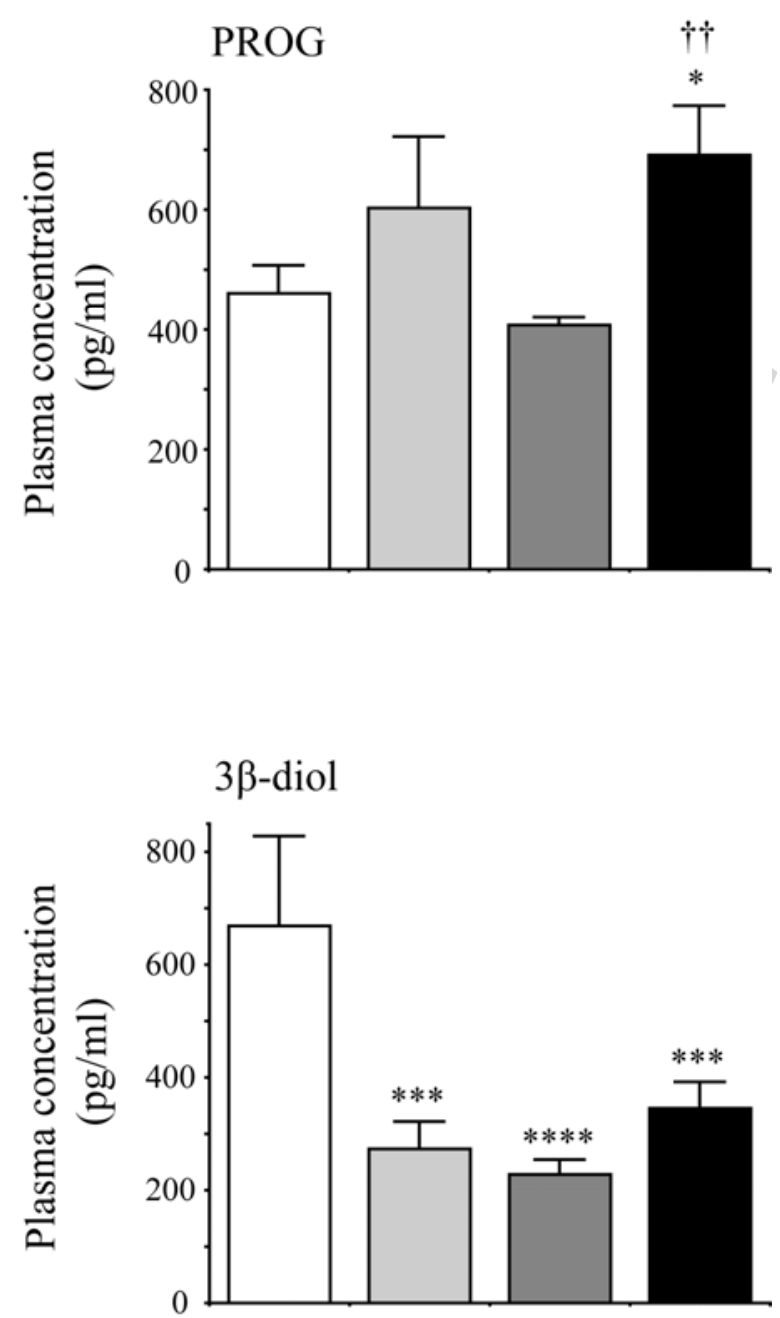

$\begin{array}{ll}\square \text { Control } & \square \text { MPTP } \\ \square \text { PROG } & \text { MPTP + PROG }\end{array}$

Figure 4. Effects of MPTP and neuroprotection with PROG treatment (experiment 1) on plasma concentration of testosterone, DHT, 3ß-diol and PROG. Mice were treated with PROG twice daily (1 $\mu \mathrm{g})$ for ten days ( 5 days before and 5 days after MPTP administration). Values shown are the means $(\mathrm{pg} / \mathrm{ml}$ or $\mathrm{ng} / \mathrm{ml}) \pm$ S.E.M. of $8-14$ mice per group. There was a statistically significant effect of treatment for testosterone $(F[3,44]=7.76 ; p=0.0003)$, DHT $(F[3,44]=5.46 ; p=0.0028), 3 \beta$-diol $(F[3,44]=7.17 ; p=0.0005)$ and PROG $(F[3,46]=3.05 ; p=0.0379) .{ }^{*} \mathrm{p}<0.05,{ }^{* *} \mathrm{p}<0.01,{ }^{* * *} \mathrm{p}<$ 0.005 and $* * * * p<0.0001$ vs control; $+p<0.05$ and $+\dagger p<0.01$ vs MPTP; $\S p<0.05$ vs PROG. 
A
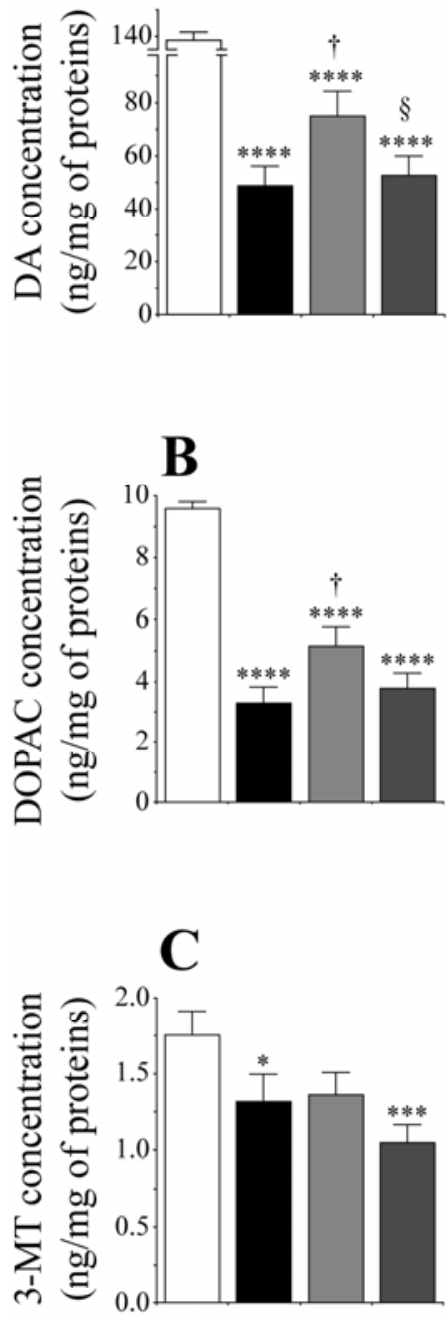

D

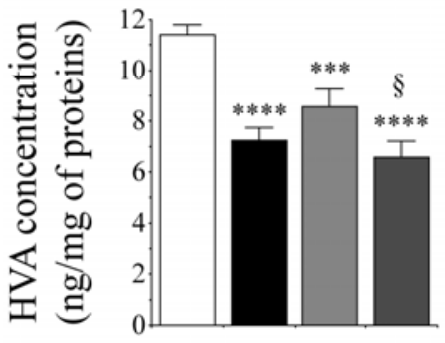

$\square$ Control

MPTP
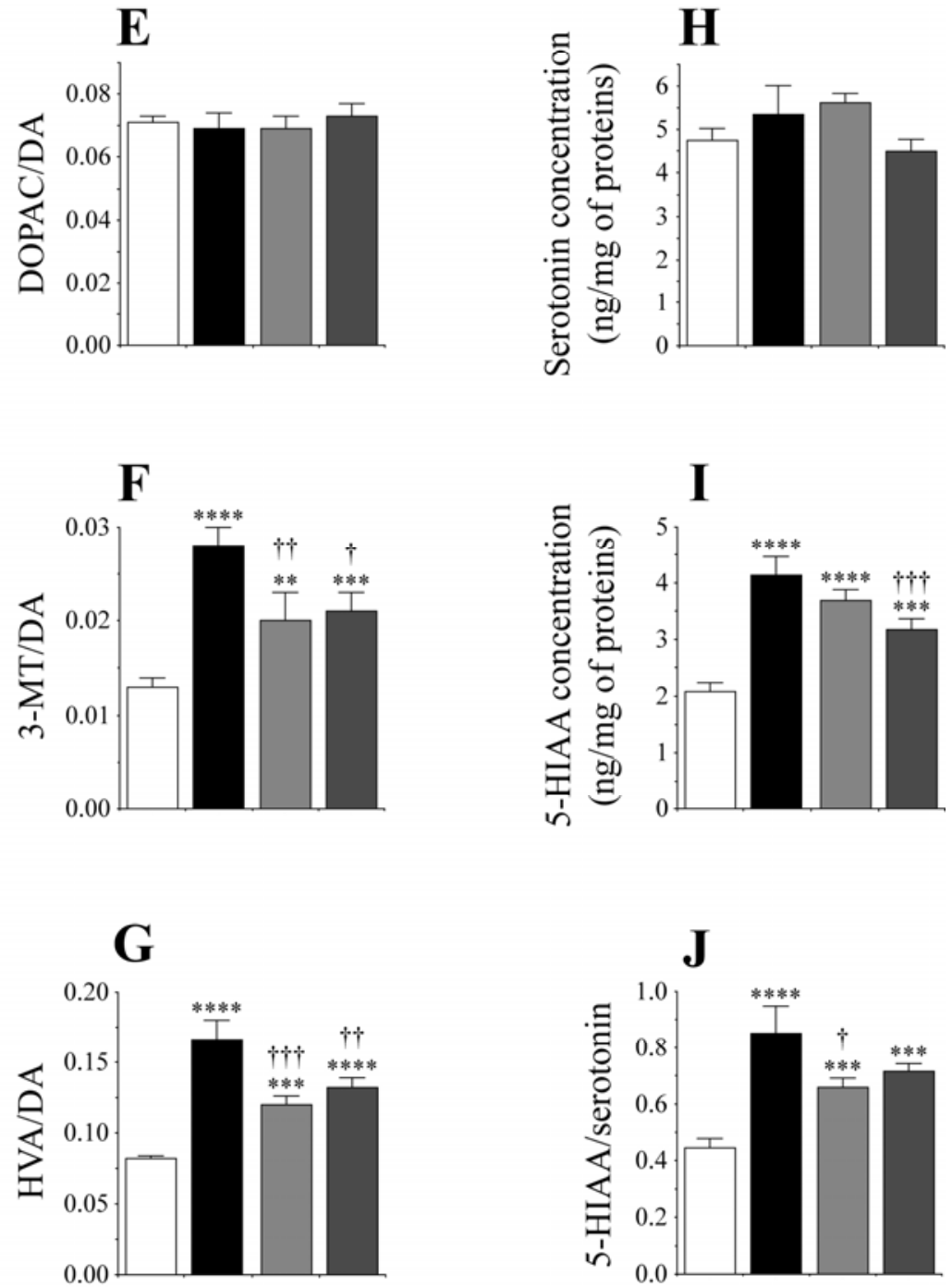

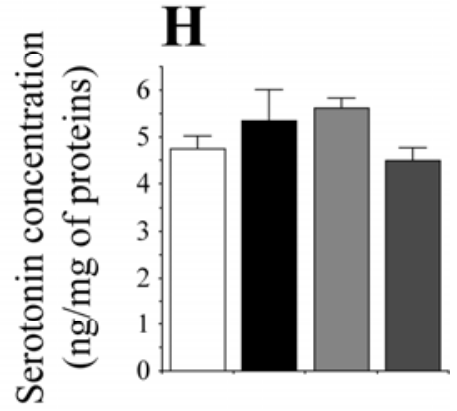

$\mathrm{MPTP}+$ PROG $8 \mathrm{mg} / \mathrm{kg}$

MPTP + PROG $16 \mathrm{mg} / \mathrm{kg}$

Figure 5. Effects of MPTP and neuroprotection with PROG treatment (experiment 2) on (A) dopamine (DA) concentrations and its metabolites (B) 3,4-dihydroxyphenylacetic acid (DOPAC), (C) 3methoxytyramine (3-MT) and (D) homovanillic acid (HVA), (E) DOPAC/DA, (F) 3-MT/DA and (G) HVA/DA ratios, as well as (H) serotonin concentrations, its metabolite (I) 5-hydroxyindoleacetic acid (5-HIAA), and (J) 5-HIAA/serotonin ratio. Mice were treated with PROG once daily $(8 \mathrm{mg} / \mathrm{kg}(191 \mu \mathrm{g})$ or $16 \mathrm{mg} / \mathrm{kg}(382 \mu \mathrm{g}))$ for 5 days starting 1 hour after the first and last injections of MPTP. Values 
shown are the means $(\mathrm{ng} / \mathrm{mg}$ of proteins) \pm S.E.M. of $10-15$ mice per group. There was a statistically significant effect of treatment for DA $(F[3,42]=43.99 ; p<0.0001)$, DOPAC $(F[3,42]=42.86 ; p<$ $0.0001), 3-\mathrm{MT}(F[3,42]=3.92 ; p=0.014), \operatorname{HVA}(F[3,42]=16.64 ; p<0.0001), 3-\mathrm{MT} / \mathrm{DA}(F[3,42]=$ $11.39 ; p<0.0001)$, HVA/DA $(F[3,42]=21,31 ; p<0.0001), 5$-HIAA $(F[3,42]=18,19 ; p<0.0001)$ and 5HIAA/serotonin $(F[3,42]=11.91 ; p<0.0001) .{ }^{*} \mathrm{p}<0.05,{ }^{* *} \mathrm{p}<0.01, * * * \mathrm{p}<0.005$ and $* * * \mathrm{p}<$ 0.0001 vs control; $+p<0.05,+\dagger p<0.01$ and $+\dagger+p<0.005$ vs MPTP; $\S p<0.05$ vs MPTP + PROG (8 $\mathrm{mg} / \mathrm{kg})$. 


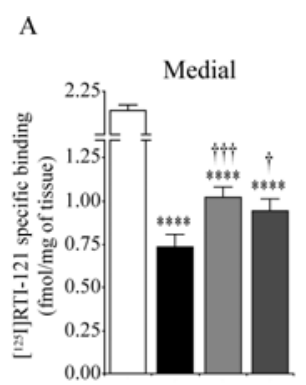

Anterior

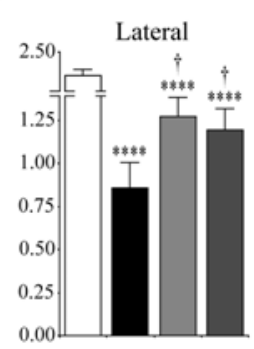

B Substantia nigra
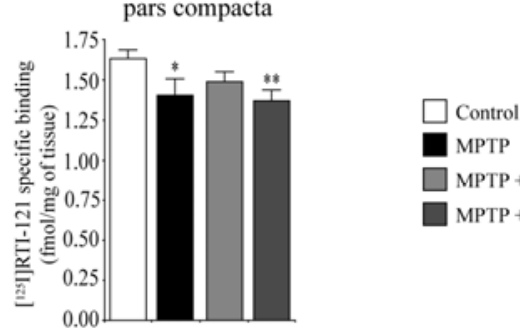

$\square$ MPTP + PROG $8 \mathrm{mg} / \mathrm{kg}$

$\square$ MPTP + PROG $16 \mathrm{mg} / \mathrm{kg}$

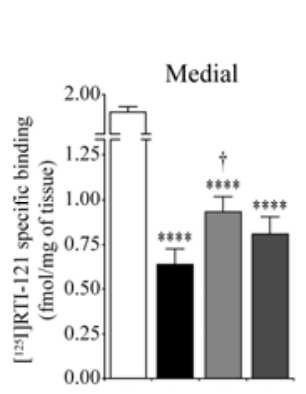

Middle

C
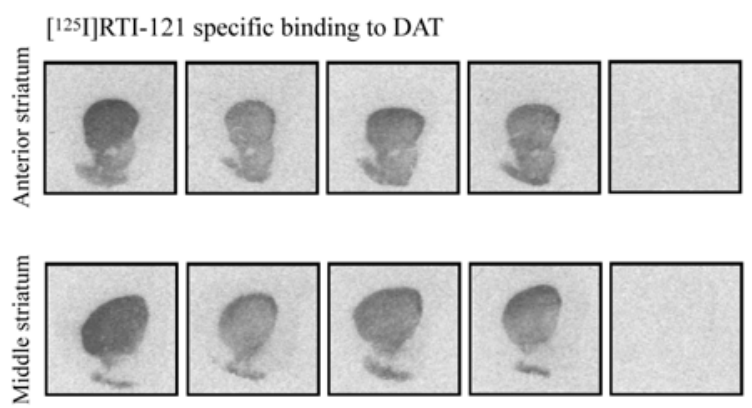

Posterior
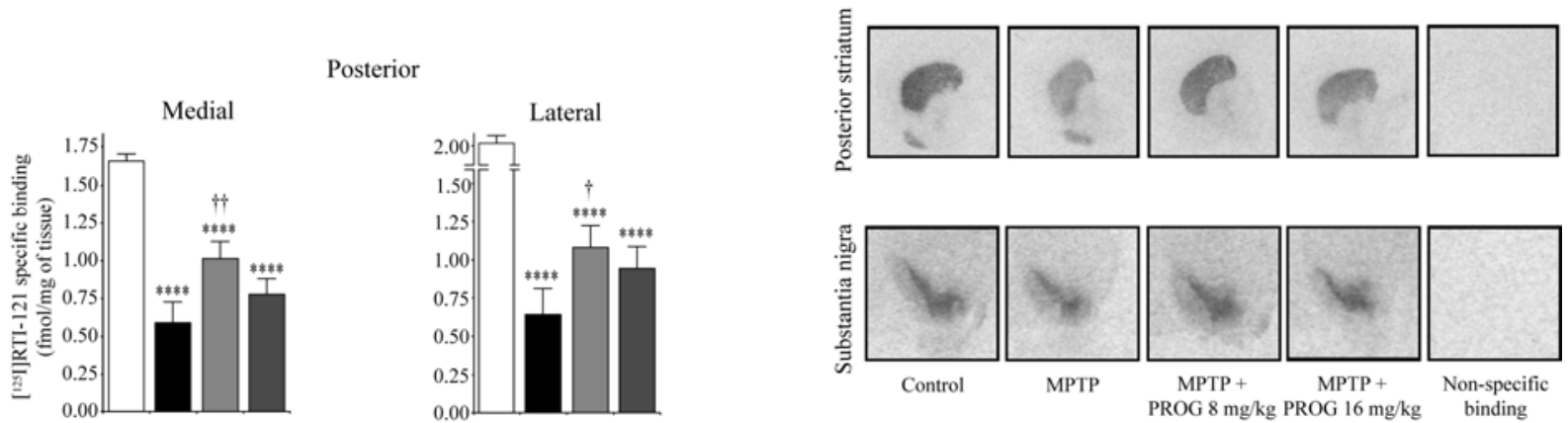

Figure 6. Effects of MPTP and neuroprotection with PROG treatment (experiment 2) on [ $\left.{ }^{125} \mathrm{I}\right]-\mathrm{RTI}-121$

DAT specific binding in (A) striatum and (B) substantia nigra pars compacta. Mice were treated with PROG once daily $(8 \mathrm{mg} / \mathrm{kg}(191 \mu \mathrm{g})$ or $16 \mathrm{mg} / \mathrm{kg}(382 \mu \mathrm{g}))$ for 5 days starting 1 hour after the first and last injections of MPTP. Values shown are the means $(\mathrm{fmol} / \mathrm{mg}$ of tissue) \pm S.E.M. of $10-15$ mice per group. There was a statistically significant effect of treatment for medial part of the anterior striatum $(F[3,42]=133.14 ; p<0.0001)$, lateral part of the anterior striatum $(F[3,42]=41.64 ; p<0.0001)$, medial part of the middle striatum $(F[3,42]=65.09 ; p<0.0001)$, lateral part of the middle striatum $(F[3,42]=32.51 ; p<0.0001)$, medial part of the posterior striatum $(F[3,42]=26.94 ; p<0.0001)$, lateral part of the posterior striatum $(F[3,42]=26.37 ; p<0.0001)$ and for substantia nigra $(F[3,41]=$ 3.17; $p=0.034){ }^{*} \mathrm{p}<0.05, * * \mathrm{p}<0.01$ and $* * * * \mathrm{p}<0.0001$ vs control; $+\mathrm{p}<0.05,+\dagger \mathrm{p}<0.01$ and ††+ $p<0.005$ vs MPTP. C. Representative examples of autoradiograms showing [ $\left.{ }^{125} \mathrm{I}\right]-\mathrm{RTI}-121$ binding to DAT in striatum and substantia nigra. 

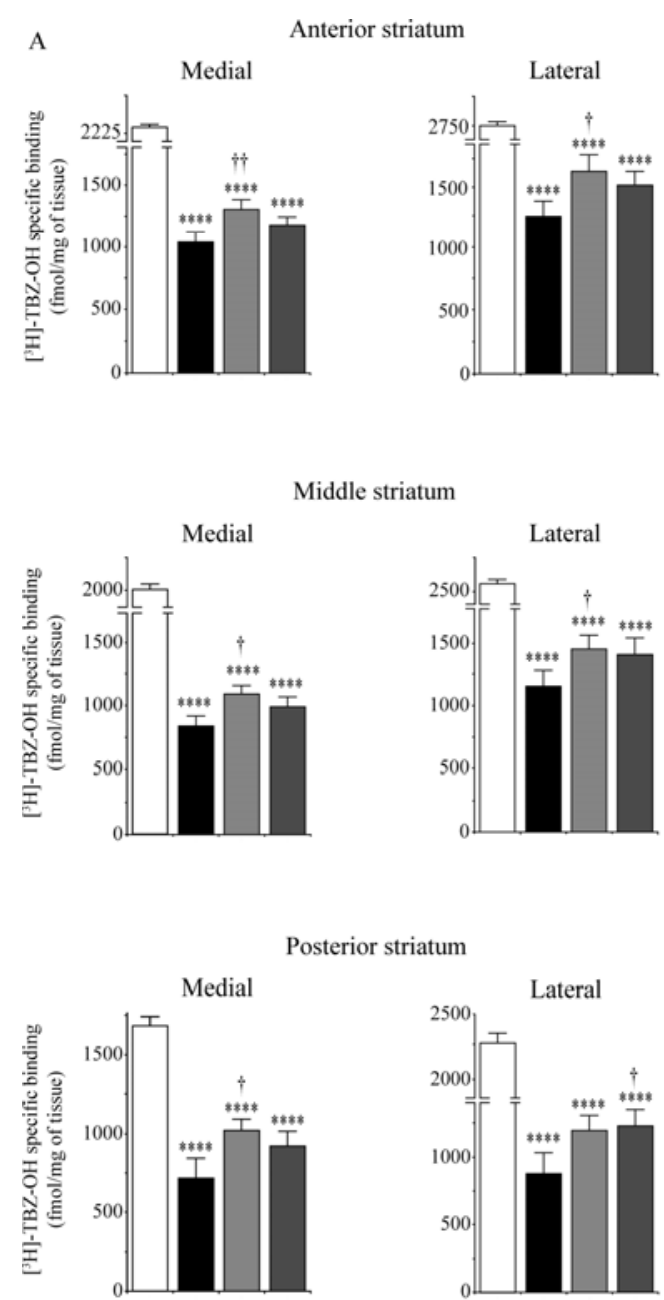

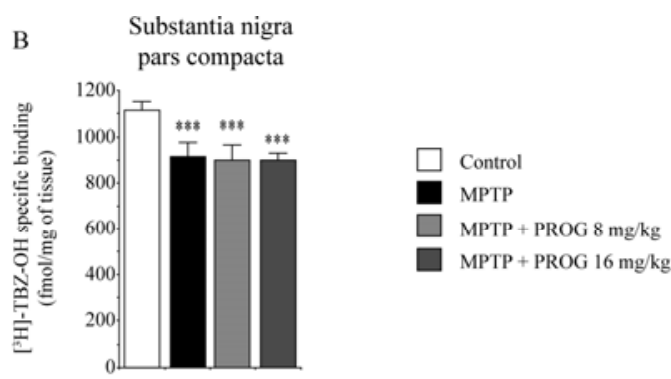

C
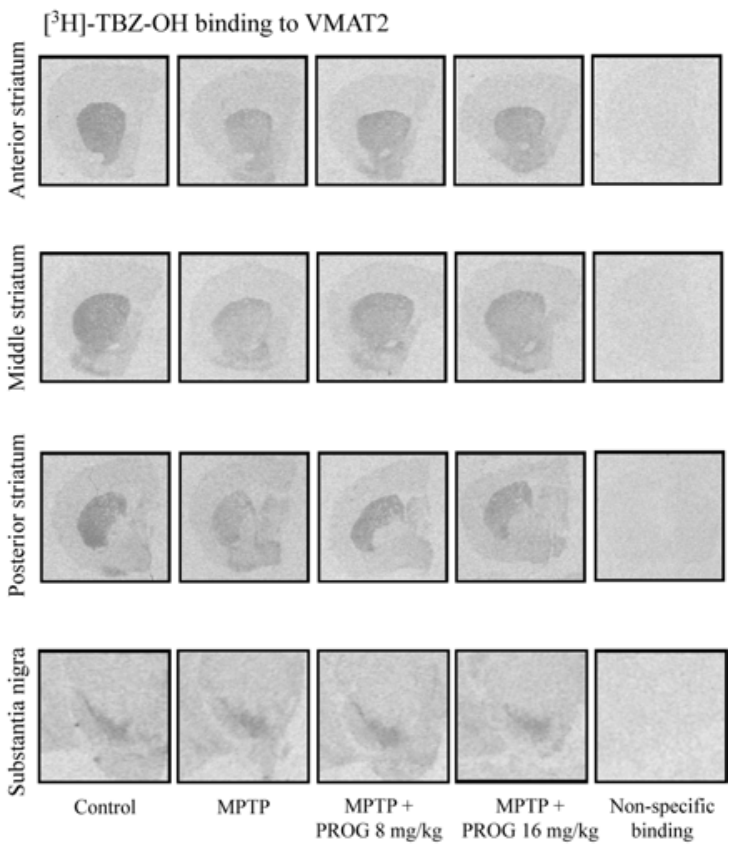

Figure 7. Effects of MPTP and neuroprotection with PROG treatment (experiment 2) on $\left[{ }^{3} \mathrm{H}\right]-\mathrm{TBZ}-\mathrm{OH}$ VMAT2 specific binding in (A) striatum and (B) substantia nigra pars compacta. Mice were treated with PROG once daily ( $8 \mathrm{mg} / \mathrm{kg}(191 \mu \mathrm{g})$ or $16 \mathrm{mg} / \mathrm{kg}(382 \mu \mathrm{g})$ ) for 5 days starting 1 hour after the first and last injections of MPTP. Values shown are the means ( $\mathrm{fmol} / \mathrm{mg}$ of tissue) \pm S.E.M. of $10-15$ mice per group. There was a statistically significant effect of treatment for medial part of the anterior striatum $(F[3,42]=105.13 ; p<0.0001)$, lateral part of the anterior striatum $(F[3,42]=54.95 ; p<$ $0.0001)$, medial part of the middle striatum $(F[3,42]=68.40 ; p<0.0001)$, lateral part of the middle striatum $(F[3,42]=47.32 ; p<0.0001)$, medial part of the posterior striatum $(F[3,41]=28.64 ; p<$ $0.0001)$, lateral part of the posterior striatum $(F[3,41]=30.21 ; p<0.0001)$ and for substantia nigra $(F[3,39]=5.63 ; p=0.002) .{ }^{* * *} p<0.005$ and ${ }^{* * * *} p<0.0001$ vs control; $+p<0.05$ and $+\dagger p<0.01$ vs MPTP. C. Representative examples of autoradiograms showing $\left[{ }^{3} \mathrm{H}\right]-\mathrm{TBZ}-\mathrm{OH}$ binding to VMAT2 in striatum and substantia nigra. 


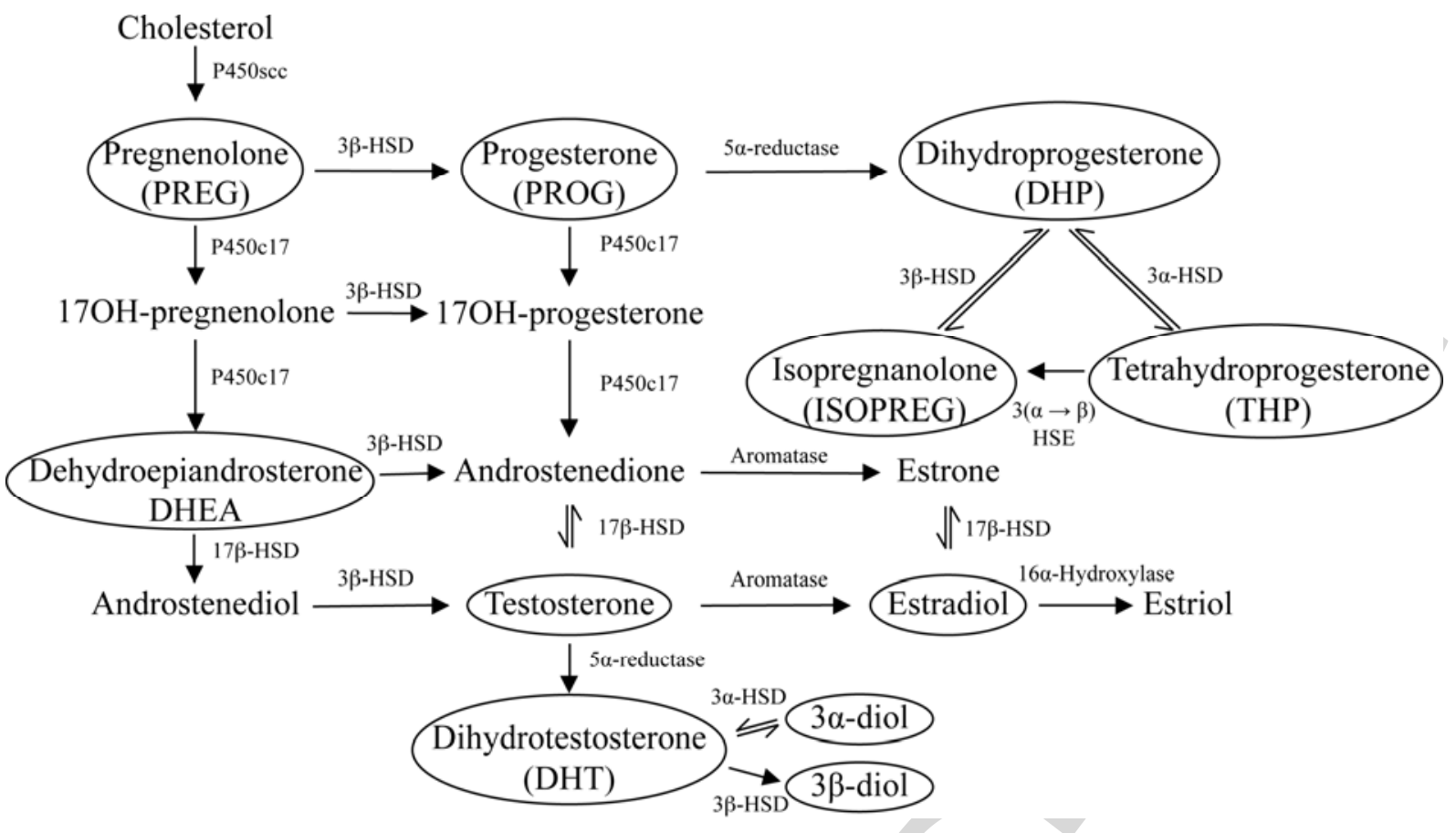

Figure 8. Schematic representation of biosynthesis pathways of steroids assayed (encircled steroids were assayed). P450scc, cytochrome P450 side-chain cleavage; P450c17, cytochrome P450 17 $\alpha$ -

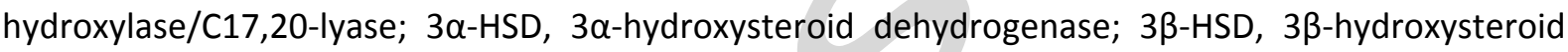
dehydrogenase; $3(\alpha \rightarrow \beta)$ HSE, 3( $\alpha \rightarrow \beta)$ hydroxysteroid epimerase; $17 \beta$-HSD, 17 $\beta$-hydroxysteroid dehydrogenase. 
믐 $\begin{array}{ll}\text { Control } & \text { MPTP }+ \text { PROG } 8 \mathrm{mg} / \mathrm{kg} \\ \mathrm{MPTP}+\text { PROG } 16 \mathrm{mg} / \mathrm{kg}\end{array}$
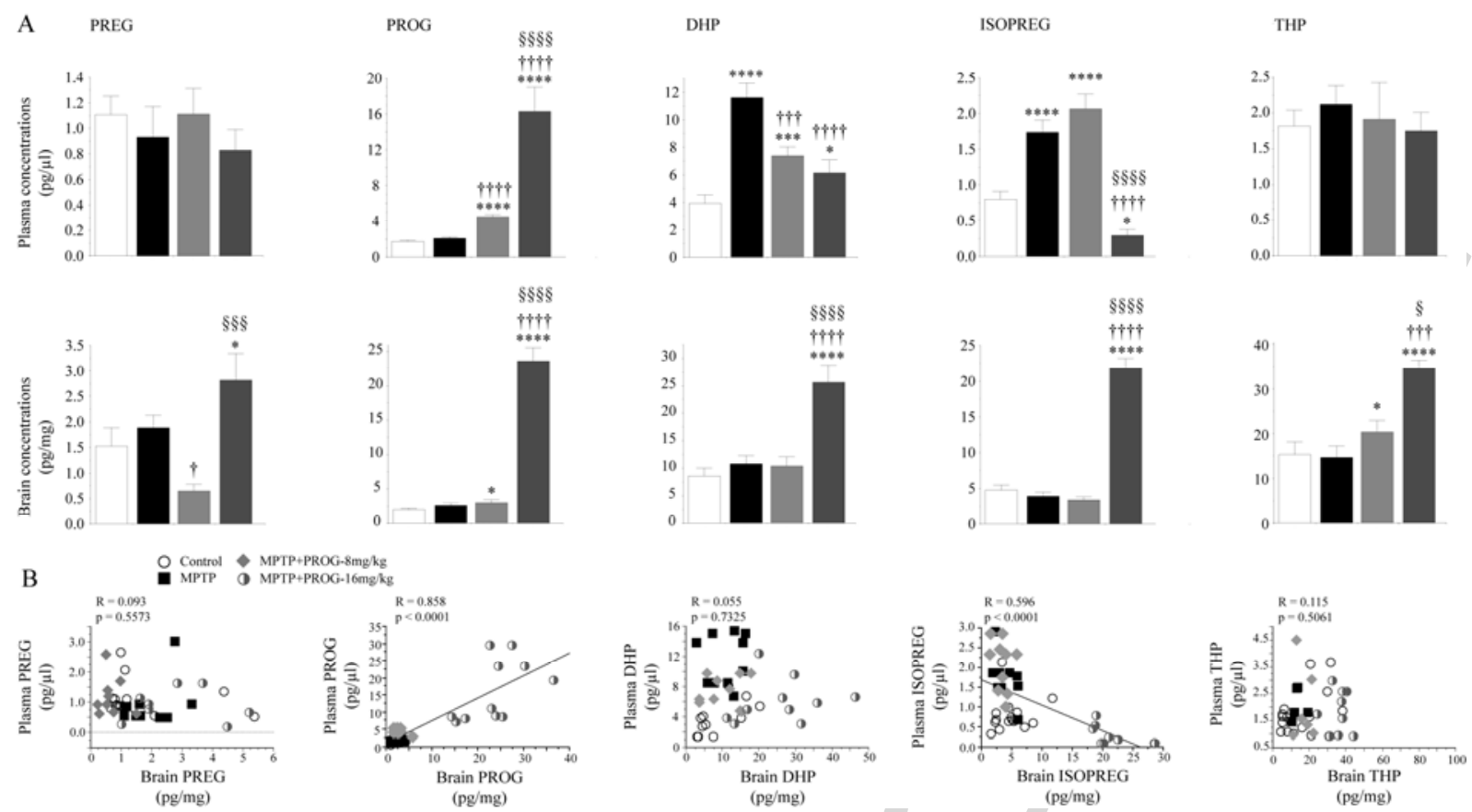

Figure 9. A. Effects of MPTP and neuroprotection with PROG treatment (experiment 2) on plasma and brain concentration of PREG, PROG, DHP, ISOPREG and THP. Mice were treated with PROG once daily $(8 \mathrm{mg} / \mathrm{kg}(191 \mu \mathrm{g})$ or $16 \mathrm{mg} / \mathrm{kg}(382 \mu \mathrm{g}))$ for 5 days starting 1 hour after the first and last injections of MPTP. Values shown are the means $(\mathrm{pg} / \mu \mathrm{l}$ or $\mathrm{pg} / \mathrm{mg}) \pm$ S.E.M. of $10-15$ mice per group. There was a statistically significant effect of treatment for plasma PROG $(F[3,41]=70.83 ; p<0.0001)$, plasma $\operatorname{DHP}(F[3,38]=15.81 ; p<0.0001)$, plasma ISOPREG $(F[3,40]=27.88 ; p<0.0001)$, brain PREG $(F[3,38]=5.25 ; p=0.004)$, brain PROG $(F[3,41]=89.59 ; p<0.0001)$, brain $\operatorname{DHP}(F[3,41]=15.13 ; p<$ 0.0001), brain ISOPREG $(F[3,41]=105.79 ; p<0.0001)$ and brain THP $(F[3,40]=9.16 ; p<0.0001) .{ }^{*} p<$ $0.05, * * * p<0.005$ and $* * * * p<0.0001$ vs control; $+p<0.05,++\dagger p<0.005$ and $+++\dagger p<0.0001$ vs MPTP; $\S p<0.05, \S \S \S p<0.005$ and $\S \S \S \S p<0.0001$ vs MPTP + PROG $(8 \mathrm{mg} / \mathrm{kg})$. B. Correlations between plasma and brain concentration of each steroid. Each symbol represents an individual mouse. 

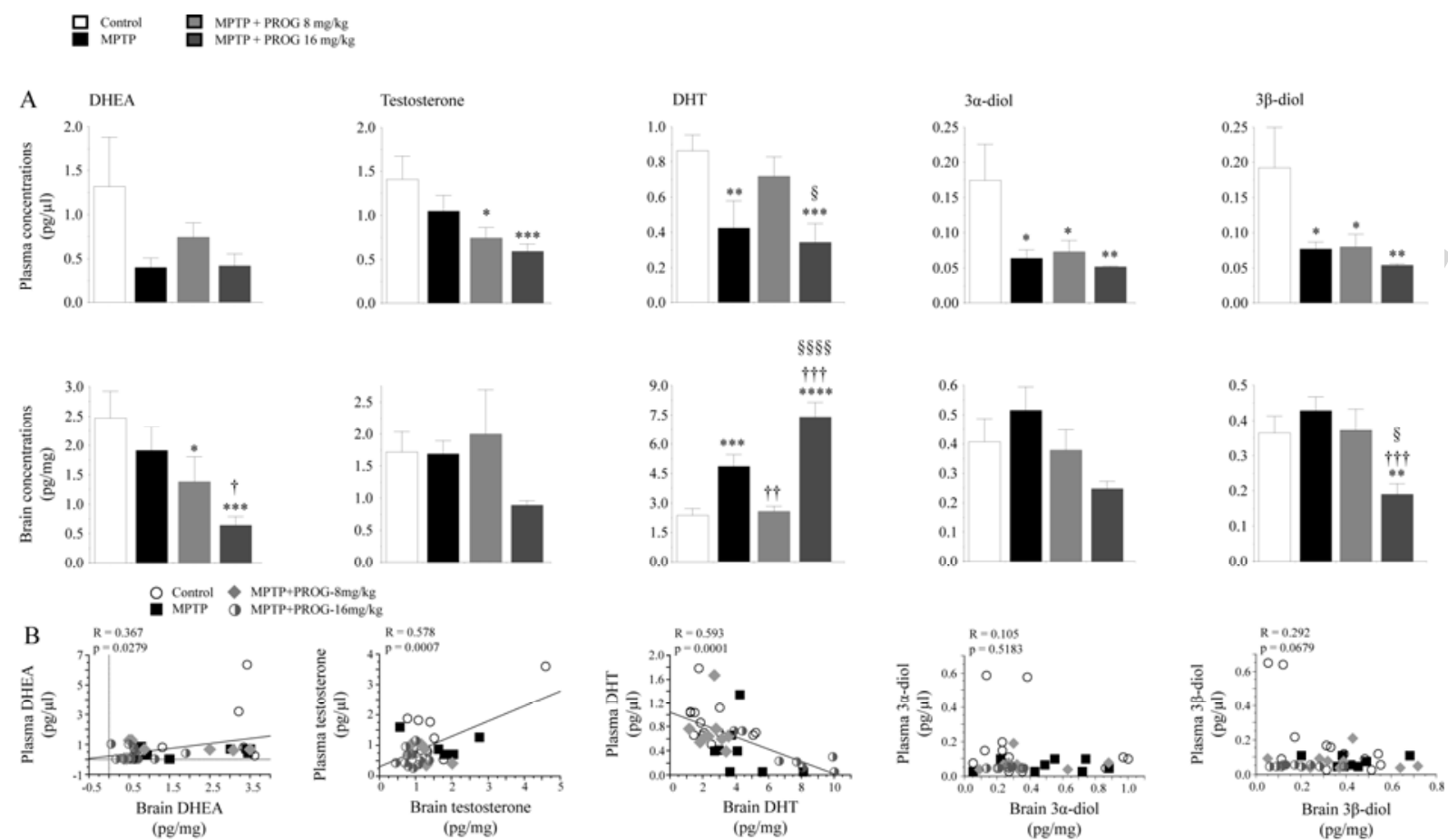

Figure 10. A. Effects of MPTP and neuroprotection with PROG treatment (experiment 2) on plasma and brain concentration of DHEA, testosterone, DHT, $3 \alpha$-diol and $3 \beta$-diol. Mice were treated with PROG once daily $(8 \mathrm{mg} / \mathrm{kg}(191 \mu \mathrm{g})$ or $16 \mathrm{mg} / \mathrm{kg}(382 \mu \mathrm{g}))$ for 5 days starting 1 hour after the first and last injections of MPTP. Values shown are the means $(\mathrm{pg} / \mu \mathrm{l}$ or $\mathrm{pg} / \mathrm{mg}) \pm$ S.E.M. of $10-15$ mice per group. There was a statistically significant effect of treatment for plasma testosterone $(F[3,29]=$ 4.311; $p=0.015)$, plasma DHT $(F[3,35]=4.68 ; p=0.007)$, plasma $3 \alpha$-diol $(F[3,37]=3.07 ; p=0.039)$, plasma 3ß-diol $(F[3,36]=2.93 ; p=0.046)$, brain DHEA $(F[3,38]=4.55 ; p=0.008)$, brain DHT $(F[3,40]=$ 20.374; $p<0.0001)$ and brain $3 \beta$-diol $(F[3,42]=4.44 ; p=0.008){ }^{*} p<0.05, * * p<0.01, * * * p<0.005$ and $* * * * p<0.0001$ vs control; $+p<0.05$ and $++\dagger p<0.005$ vs MPTP; $\S p<0.05$ and $\S \S \S \S p<0.0001$ vs MPTP + PROG $(8 \mathrm{mg} / \mathrm{kg})$. B. Correlations between plasma and brain concentration of each steroid. Each symbol represents an individual mouse. 
Neuroendocrinology (International Journal for Basic and Clinical Studies on Neuroendocrine Relationships)

Journal Editor: Millar R.P. (Edinburgh)

ISSN: 0028-3835 (Print), elSSN: 1423-0194 (Online)

www.karger.com/NEN

Disclaimer: Accepted, unedited article not yet assigned to an issue. The statements, opinions and data contained in this publication are solely those of the individual authors and contributors and not of the publisher and the editor(s). The publisher and the editor(s) disclaim responsibility for any injury to persons or property resulting from any ideas, methods, instructions or products referred to in the content. Copyright: All rights reserved. No part of this publication may be translated into other languages, reproduced or utilized in any form or by any means, electronic or mechanical, including photocopying, recording, microcopying, or by any information storage and retrieval system, without permission in writing from the publisher or, in the case of photocopying, direct payment of a specified fee to the Copyright Clearance Center.

(C) 2015 S. Karger AG, Basel 